\title{
Oncolytic viral therapies - the clinical experience
}

\author{
Manish Aghi*, ${ }^{1}$ and Robert L Martuza ${ }^{1}$ \\ ${ }^{1}$ Department of Neurosurgery, Massachusetts General Hospital, White Building Room 502, 55 Fruit Street, Boston, MA 02114, USA
}

\begin{abstract}
It has been 9 years since the beginning of the first clinical trial in which an oncolytic virus was administered to cancer patients. Since then, oncolytic viruses from five different species have been taken to phase I and II clinical trials in over 300 cancer patients. While additional studies will be required to ascertain if the efficacy of any of these agents is high enough to warrant adding them to the existing therapeutic regimen, it has been reassuring that DNA viruses engineered to achieve tumor selectivity and RNA viruses with relative inherent natural tumor selectivity have proven reasonably safe at the wide range of doses that were tested. Here, we review the biology and clinical results of these five species of viruses and discuss lessons learned and challenges for the future.

Oncogene (2005) 24, 7802-7816. doi:10.1038/sj.onc.1209037
\end{abstract}

Keywords: oncolytic virus; clinical trials; adenovirus; herpesvirus; vaccinia virus; Newcastle disease virus

\section{Introduction}

Clinicians have taken advantage of virus' ability to lyse human cells by using various wild-type viruses to treat cancer over the last century, but the approach was temporarily abandoned due to toxicity (Southam, 1960). With the discovery of recombinant technology, however, it became possible to genetically engineer DNA viruses to enhance their safety by increasing their selectivity for tumor cells, an approach first demonstrated in 1991 with herpes simplex virus type one (HSV1) in an experimental glioma model (Martuza et al., 1991). At 5 years later, the engineered adenovirus Onyx015 became the first engineered oncolytic virus to undergo a clinical trial in cancer patients (Ganly et al., 2000). Meanwhile, it was found that certain RNA viruses or their naturally occurring attenuated mutant strains possessed intrinsic tumor selectivity without the need for genetic engineering in the laboratory. Now, cancer has become the foremost arena in which gene therapy is applied - a recent summary of 1020 open and closed gene therapy clinical trials from 1990 to 2004 found that 675 trials $(66 \%)$ were in the area of cancer. In contrast, despite the purpose of the first gene therapy clinical trial in 1989 being for gene replacement to treat

*Correspondence: M Aghi; E-mail: maghi@partners.org a monogenetic disorder, only $9 \%$ of clinical trials thereafter have been in this category (Edelstein, 2005).

Cancer gene therapy involves intratumoral, intracavitary, or intravascular administration of a viral vector whose gene products impede the survival and growth of tumor cells left behind after surgery or other therapies. Oncolytic vectors are viruses with intrinsic or engineered tumor selectivity that lyse tumor cells, while nonlytic vectors express transgenes that generate an anticancer effect. As with conventional therapies, the selectivity of this approach is not perfect, but localized vector delivery to the tumor allows for some selectivity of viral uptake. Additionally, the use of viruses that only propagate in dividing cells or transgenes driven by tumor-specific promoters confers additional selectivity.

Of the 675 initiated cancer gene therapy clinical trials, oncolytic viruses have been the focus of slightly over half, with the remainder utilizing nonlytic vectors such as retrovirus, adeno-associated virus (AAV), plasmid DNA, lipofection, RNA transfer, gene gun, and bacteria. The oncolytic viruses with which clinical experience has been reported consist of three DNA viruses engineered in the laboratory to achieve tumor selectivity (adenovirus, HSV, and vaccinia) and two wild-type or spontaneously arising attenuated RNA viruses with intrinsic tumor selectivity (Newcastle disease virus (NDV) and reovirus). Measles virus will be added to the second group once results of a phase I trial in patients with ovarian cancer are published. This review focuses on the reported clinical experience in treating cancer patients with these five types of oncolytic viruses.

Biology of the oncolytic viruses used in cancer clinical trials

\section{$D N A$ viruses engineered in the laboratory to achieve tumor selectivity}

Herpesviruses HSV-1 is an enveloped, double-stranded linear DNA virus whose genome spans $152 \mathrm{~kb}$ encoding over 80 genes. Approximately half of the genes are necessary for virus replication. The HSV-1 genome is composed of unique long $\left(\mathrm{U}_{\mathrm{L}}\right)$ and unique short $\left(\mathrm{U}_{\mathrm{S}}\right)$ segments, which are both flanked by inverted repeats (Figure 1).

Infection can be either lytic or latent. During lytic infection, HSV-1 genes are expressed in a temporally 


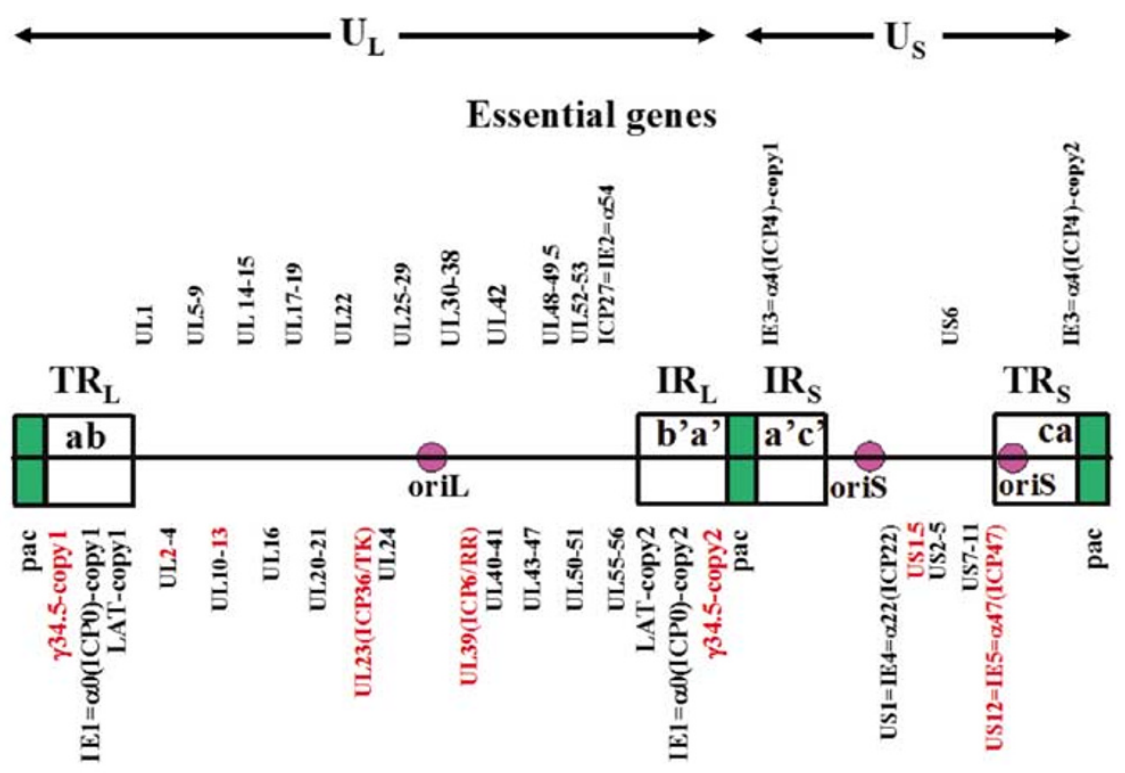

\section{Non-essential genes}

Figure 1 HSV-1 genome. HSV-1 possesses a linear, double-stranded DNA genome of $152 \mathrm{~kb}$ encoding more than 80 genes. The genome is composed of unique long $\left(\mathrm{U}_{\mathrm{L}}\right)$ and unique short $\left(\mathrm{U}_{\mathrm{S}}\right)$ segments, which are flanked by inverted repeats. The inverted repeats are designated as follows: $\mathrm{TR}_{\mathrm{L}}$ : terminal repeat of the long segment; $\mathrm{IR}_{\mathrm{L}}$ : internal repeat of the long segment; $\mathrm{IR}_{\mathrm{S}}$ : internal repeat of the short segment; and $T R_{S}$ : terminal repeat of the short segment. The repeats surrounding $U_{L}$ are designated ab and $b^{\prime} a^{\prime}$, while the repeats surrounding $\mathrm{U}_{\mathrm{S}}$ are designated $\mathrm{a}^{\prime} \mathrm{c}^{\prime}$ and ca. There are two different origins of replication, oriL in the long segment and oriS in the short segment. OriS is duplicated, along with ICP4, because they are found in the inverted repeats surrounding the short segment. Similarly, $\gamma 34.5$, ICP0, and LAT are duplicated because they are found in the inverted repeats surrounding the long segment. Approximately half of the genes are essential for viral replication in cell culture and are labeled above the genome. The other half are nonessential for replication and are labeled below the genome. The open reading frames are read from left to right. Genes labeled in red represent nonessential genes that are mutated in several of the replication-conditional viruses studied in brain tumor therapy and described in the text. The genome contains three pac signals (shown in green) that assist in packaging the DNA into virions

regulated cascade consisting of three phases, designated $\alpha, \beta$, and $\gamma$. The $\alpha$ gene products regulate gene transcription, and include $\alpha 47$ (ICP47/IE5/US12), whose product inhibits the transporter associated with antigen presentation (TAP), leading to decreased MHC class I expression in infected cells. The $\beta$ gene products promote viral DNA synthesis, and include viral DNA polymerase, the large subunit of viral ribonucleotide reductase (RR), and herpes simplex virus type 1 thymidine kinase (HSV-TK). The $\gamma$-gene products create an environment favorable for protein synthesis, contribute to encapsulation of viral DNA, and promote viral envelopment. $\gamma 34.5$ is one of three HSV-1 genes that are duplicated because they are found in inverted repeats. The $\gamma 34.5$ gene product performs two functions: (1) it allows the replication of viral DNA, even in nonreplicating cells such as postmitotic neurons, contributing to HSV-1 neurovirulence; and (2) it prevents the shutoff of host protein synthesis that occurs in response to infection, thereby preventing the host from inducing apoptosis of infected cells prior to viral replication.

HSV-1 offers a number of advantages over other viral vector systems (Table 1). These advantages include (1) the potential for incorporating a large payload of foreign DNA - approximately $30 \mathrm{~kb}$ of the HSV-1 genome, including the $15 \mathrm{~kb}$ of inverted repeats that flank the $\mathrm{U}_{\mathrm{L}}$ and $\mathrm{U}_{\mathrm{S}}$ sequences, can be replaced by foreign genes with minimal effects on titers or replication; (2) neurotropism, rendering gene delivery to the CNS more effective; (3) the sensitivity to antiherpetic agents like acyclovir or ganciclovir $(\mathrm{GCV})$ provides a safety mechanism by which viral replication could be abrogated; and (4) the fact that HSV-1 never integrates and persists as an episome even during latency ensures that the risk of insertional mutagenesis posed by retroviral vectors is not an issue with HSV-1 vectors, while the lack of integration with HSV-1 vectors is not a concern with cancer gene therapy, as immediate tumor killing likely does not require long-term gene expression.

However, there are challenges that arise when working with HSV-1 vectors. First, genetic manipulation of HSV-1 is difficult due to the large size of the viral DNA. A second potential obstacle when using HSV-1 recombinant vectors is the fact that most humans have preexisting herpes immunity, which could potentially impair gene delivery. Approximately $90 \%$ of the adult population has been exposed to HSV-1 as determined by the detection of viral DNA and antibodies to HSV-1 in serum (Boviatsis et al., 1994b). Potential neurotoxicity is a third problem inherent to HSV-1 vectors when delivered into the central nervous system. HSV-1 is a neurotrophic human pathogen that can cause a lifethreatening encephalitis from primary infection or from 
Table 1 General biology, advantages, and disadvantages of various viral vectors for cancer gene therapy

\begin{tabular}{|c|c|c|c|c|c|}
\hline & $H S V-1$ & Adenovirus & Vaccinia virus & Reovirus & $N D V$ \\
\hline Genetic material & ds DNA & ds DNA & ds DNA & ds RNA & Negative ss RNA \\
\hline Transgene capacity & $30 \mathrm{~kb}$ & $10 \mathrm{~kb}$ & $25 \mathrm{~kb}$ & $\begin{array}{l}\text { Cannot be manipulated } \\
\text { at present }\end{array}$ & Not assessed \\
\hline Achievable titer & $10^{10} \mathrm{PFU} / \mathrm{ml}$ & $10^{12} \mathrm{PFU} / \mathrm{ml}$ & $10^{8} \mathrm{PFU} / \mathrm{ml}$ & $10^{9} \mathrm{PFU} / \mathrm{ml}$ & $10^{8} \mathrm{PFU} / \mathrm{ml}$ \\
\hline Life cycle & $12 \mathrm{~h}$ & $24 \mathrm{~h}$ & $8 \mathrm{~h}$ & $18 \mathrm{~h}$ & $18 \mathrm{~h}$ \\
\hline $\begin{array}{l}\text { Specific antiviral agent } \\
\text { available }\end{array}$ & $\begin{array}{l}\text { Yes - GCV or } \\
\text { acyclovir }\end{array}$ & No & $\begin{array}{l}\text { Possibly - cidofovir } \\
\text { or vaccinia } \\
\text { immunoglobulin }\end{array}$ & $\begin{array}{l}\text { Possibly - mycophenolic } \\
\text { acid }\end{array}$ & No \\
\hline Ease of genetic manipulation & Difficult & Easy & Easy & Very difficult & Difficult \\
\hline Immunogenicity & Moderate & High & High & Low & High \\
\hline $\begin{array}{l}\text { Wild-type virus infects } \\
\text { nonreplicating cells }\end{array}$ & Yes & Yes & Yes & No & No \\
\hline Virulence of wild-type virus & Yes & Slight & Slight & No & No \\
\hline
\end{tabular}

HSV-1: herpes simplex virus type 1; NDV: Newcastle disease virus; ds: double-stranded; ss: single-stranded; PFU: plaque-forming unit; GCV: ganciclovir

reactivation of latent virus. Fourth, the introduction of mutant HSVs into patients could lead to one of two scenarios that could lead to serious infections with wildtype HSV: (1) recombination with latent wild-type HSV1 could restore full replicative capacity to the introduced vector; or (2) latent wild-type HSV-1 present in most humans could be reactivated by application of HSV-1 vectors.

Because HSV-1 can infect replicating or quiescent cells, certain genes must be deleted to render the virus replication-conditional, a term used to describe viruses that replicate selectively in dividing cells. The recombinant HSV-1 viruses that have been studied as anticancer agents fall into three categories. These are (1) viruses deleted in $\beta$ genes involved in nucleic acid metabolism, such as the large subunit of viral RR; (2) viruses lacking one or both copies of the $\gamma 34.5$ gene; and (3) viruses with mutations in two or more different genes.

It is thought that $\mathrm{RR}^{-}$viruses only replicate in dividing cells because these cells express mammalian RR and complement the viral mutation. While HSV-1 vectors mutated in the large subunit of viral RR exhibit efficacy in experimental tumor models and limited neurotoxicity (Boviatsis et al., 1994a), concerns about the possible risk of reversion mutation or recombination have thus far prevented their clinical use in the form of a single gene mutation or deletion.

Viruses with deletions in $\gamma 34.5$ include 1716, which has undergone phase I clinical trials in brain tumor patients, a disease where $\gamma 34.5$-deleted viruses are appealing because of the role of $\gamma 34.5$ in HSV-1 neurovirulence. The role of $\gamma 34.5$ in promoting DNA replication renders a $\gamma 34.5$ mutant replication-conditional because only actively replicating cells express the DNA repair enzyme GADD34 whose carboxyl terminus can possibly substitute for the homologous $\gamma 34.5$ region (Brown et al., 1997).

The risks of using single mutant HSV-1 vectors include recombination with latent host virus to restore wild-type phenotype, reactivation of latent virus in the host, and suppressor mutations to restore wild-type phenotype. The risk of recombination with latent host HSV-1 has not yet been investigated. The risk of reactivation was felt to be low based on a study showing that, after adult rats were infected with wild-type HSV-1 and latency established, intracerebral inoculation of hrR3 failed to cause HSV-1 reactivation (Wang et al., 1997). There is, however, a risk of viral mutations that restore a wild-type phenotype based on a study showing that, when growing a strain of HSV-1 with a deletion of the $\gamma 34.5$ gene, a suppressor mutation in two viral genes can occur, enabling the virus to acquire the wild-type HSV-1 phenotype of sustained late protein synthesis (Mohr and Gluzman, 1996).

Concern about these risks led to the design of HSV with dual mutations. The most thoroughly studied combination has mutations in hrR3 and $\gamma 34.5$, a combination found in G207, a vector that completed phase I safety trials in brain tumor patients. The enhanced safety of double mutant HSVs can attenuate their oncolytic potential compared to single mutants in certain experimental models (Kramm et al., 1997), but for now their presumed safety makes them more readily used in clinical trials particularly for treatment of tumors in the brain.

Adenoviruses Adenoviruses are noneneveloped DNA viruses causing upper respiratory tract infections. The adenovirus vectors used for gene delivery are derived from subgroup C. Wild-type subgroup $C$ causes a mild upper respiratory infection, which resolves uneventfully in healthy individuals. The adenoviral genome is divided into E1A, E1B, E2, E3, and E4 regions, which regulate a temporal cascade of gene expression. To generate an adenoviral vector, a transgene is cloned into a plasmid bearing the adenovirus packaging signal, an E1 deletion, and some adenovirus sequences downstream from the E1 region. This plasmid is introduced into E1-expressing 293 cells along with a second plasmid bearing a packaging signal and E1 deletion. Recombination between the two plasmids generates an E1-defective virus that can replicate in 293 cells that complement the E1 deletion.

The genome contains $36 \mathrm{~kb}$ of double-stranded DNA, of which several regions can be deleted to accommodate 
up to $10 \mathrm{~kb}$ of foreign DNA. In addition, high titers (up to $10^{12}$ particles $/ \mathrm{ml}$ ) can be achieved with adenovirus. The viral genome is maintained as an extra-chromosomal element that is rapidly lost in dividing cells, but this is not a major impediment during lytic infections of tumor cells. Adenovirus only infects cells expressing coxsackievirus and adenovirus receptors (CARs) on their surface (Figure 2). CAR is only expressed by some human tumor cells and, without genetic engineering to alter viral molecules that bind CAR, adenovirus therapy can only be used to treat CAR-expressing tumors like prostate cancer, whose CAR expression increases with Gleason score (Rauen et al., 2002). Oncolytic adenoviruses are highly immunogenic, which can be advantageous if it leads to an antitumor immune response, but can also be a disadvantage if the immune response blocks viral propagation or leads to toxicity. Indeed, the immunogenic nature of adenovirus may have contributed to the death of an 18-year-old patient after an arterial infusion of a replication-defective adenovirus vector during a gene therapy trial for ornithine transcarbamylase deficiency (Assessment of adenoviral vector safety and toxicity: report of the National Institutes of Health Recombinant DNA Advisory
Committee, 2002). This death was attributed to a massive cytokine response to the adenovirus vector, resulting in disseminated intravascular coagulation.

One deletion that confers tumor selectivity is deletion of the E1B region, found in the vector ONYX-015, the first oncolytic virus used in a clinical trial and the subject of 18 of 35 oncolytic virus clinical trials whose results have been published. The E1B deletion in ONYX-015 restricts viral replication to cells lacking a normal p53 protein since E1B's ability to sequester p53 is essential to viral replication (Bischoff et al., 1996). This vector was initially appealing because of potential applicability in the $40 \%$ of human cancers carrying p53 mutations (Vogelstein and Kinzler, 2004). However, the virus proved capable of infecting some cultured cells lacking p53 mutations (Goodrum and Ornelles, 1998). And a recent study showed that tumor cells that support ONYX-015 replication may do so by providing the function of E1B in late viral RNA export (O'Shea et al., 2004).

Vaccinia virus Vaccinia virus is a double-stranded enveloped lytic DNA virus with a linear genome whose entire life cycle takes place within the cytoplasm of host

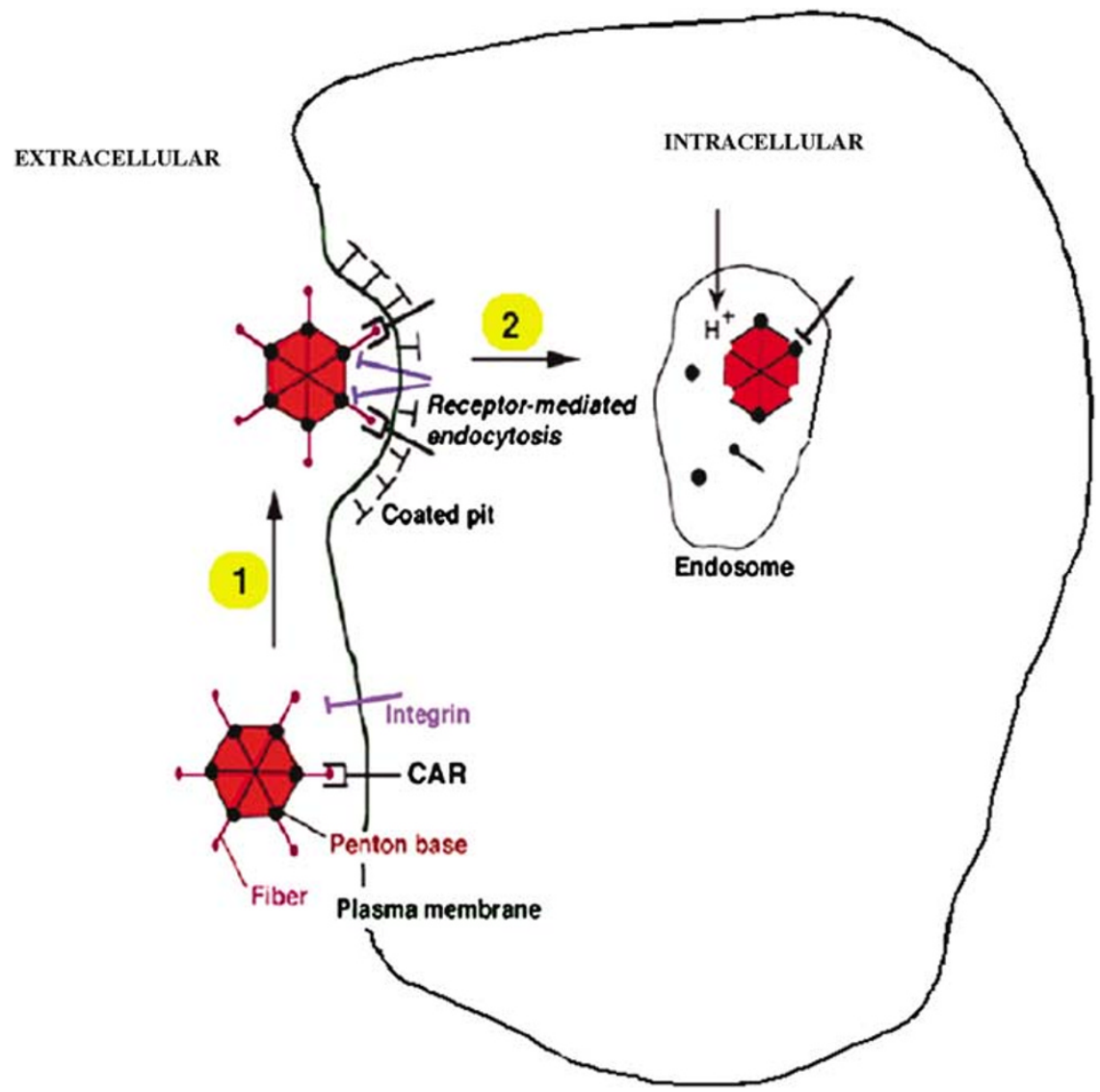

Figure 2 Entry of adenovirus into cells via specific binding of a viral ligand to a cell surface receptor. Adenovirus serotype 5 (Ad5), the most common serotype employed in gene transfer, enters cells through the following series of steps: (1) specific binding of virion surface fiber molecules (labeled fiber above) to the CAR; (2) adenovirus internalization is then initiated after the interaction of the penton base protein with cell surface integrins $\alpha_{v} \beta_{3}$ and $\alpha_{v} \beta_{5}$; (3) receptor-mediated endocytosis then occurs; and (4) virion particles are disassembled in the acidic environment of the endosome. Once tumor-specific receptors are identified, genetic modification of the virion surface molecules that bind CAR will be needed to target tumor cells not expressing CAR 
cells. Vaccinia virus was named because it was felt to arise around 1930 as a natural derivative of a cowpox strain that was serially passaged while being used as a smallpox vaccine. Vaccinia virus has several advantages over other oncolytic viruses. Unlike adenovirus, vaccinia virus can infect cells from a variety of animal models and a variety of cell types. Vaccinia virus can be stored as dry power for prolonged periods of time without significant loss of infectivity. Other benefits include large DNA size capability (up to $25 \mathrm{~kb}$ ) and easy manipulability, replication exclusively in the cytoplasm eliminating any risk of integration, and short replication cycle. Initial concerns about vaccinia virus' immunogenicity making repeat injections impossible were alleviated by the finding that vaccinia treatment was as effective in vaccinated as nonvaccinated animals (Lee et al., 1994). Vaccinia virus' ability to replicate in a wide spectrum of human cells raises concerns about toxic side effects if the virus were shed into the bloodstream, which could affect not only treated patients, but also their relatives and contacts. Should unwanted replications occur, vaccinia immunoglobulin (Enserink, 2002) or the antiviral agent cidofovir may offer protection against vaccinia replication, but further study will be necessary to definitively determine their efficacy.

\section{$R N A$ viruses whose wild-type form or natural attenuated mutants exhibit intrinsic tumor selectivity}

Double-stranded RNA formation is a hallmark of the life cycle of RNA viruses. The presence of doublestranded RNA activates PKR, a serine/threonine protein kinase that inhibits protein synthesis and promotes apoptosis. Double-stranded RNA also stimulates the release of interferons, which activate PKR in adjacent uninfected cells, thereby protecting these cells from viral infection. Selective replication in tumor cells may arise from defective PKR and/or interferon pathways in tumor cells, although there appear to be specific differences in the mechanisms of selective oncolysis between the various RNA viruses.

Reovirus This nonenveloped DNA virus belongs to the genus Orthoreoviridae of the family Reoviridae, which consists of viruses with segmented double-stranded RNA genomes. Reoviruses contain 10 segments of double-stranded RNA and are apparently nonpathogenic to humans, causing only mild infections limited to the gastrointestinal or respiratory tract. Reoviruses achieve tumor selectivity because they can replicate relatively selectively in cells with an activated Ras pathway, and approximately $30 \%$ of human tumors possess an activating mutation of the Ras pathway. The Ras pathway induces an endogenous protein inhibitor of PKR activation. Thus, in cells with an activated Ras pathway, the PKR-mediated responses to doublestranded RNA and interferon are defective. In nontumorous cells, early reovirus transcripts trigger PKR phosphorylation, which in turn leads to inhibition of translation of viral genes and control of virus infection. In Ras-transformed cells, this protective pathway is blocked, and viral replication proceeds unchecked.

Administered intravenously to animals bearing subcutaneous tumors, potent antitumor activity occurs in a variety of tumor types (Coffey et al., 1998). In contrast to the other viruses described here, there is still no satisfactory system to generate recombinant reoviruses with specifically engineered mutations, due in part to technical challenges posed by the presence of 10 doublestranded RNA segments in the reoviral genome. Mycophenolic acid, an immunosuppressive agent used in kidney transplant agents, has been shown to inhibit reoviral replication (Hermann and Coombs, 2004).

$N D V$ NDV is an avian virus belonging to the Rubulavirus genus of the Paramyxoviridae family, a family of enveloped, nonsegmented, negative-stranded RNA viruses. NDV was first noted to replicate in and destroy tumor cells in 1955. The virus is not pathogenic to humans. Tumor selectivity is believed to arise from viral induction of tumor necrosis factor (TNF)- $\alpha$ secretion by peripheral blood mononuclear cells (PBMCs) and viral enhancement of sensitivity of neoplastic cells to the cytotoxic effects of TNF- $\alpha$ (Lorence et al., 1988). The most characterized oncolytic strain of NDV is 73-T, so named because it was passaged through mouse ascites tumor cells 73 times in vitro. Advantages of NDV in oncolysis include (1) rapid growth and (2) ability to stimulate an antitumoral immune response.

\section{Clinical experience with oncolytic viruses}

\section{Adenovirus}

The first virus studied in clinical trials is the adenovirus ONYX-015, which has been the subject of 18 phase I and II clinical trials with published results, starting in 1996. Because it has undergone the most clinical investigation, important lessons can be drawn from the general strategy utilized for ONYX-015. The strategy has involved a progression from demonstrating safety of intratumoral administration, followed by intracavitary installation (intraperitoneal), intra-arterial infusion (hepatic artery), and eventually intravenous administration. In addition, only patients with advanced incurable cancers were initially enrolled. Once safety was demonstrated, patients with premalignant conditions were enrolled. Finally, as a result of results in more clinical trials than any other oncolytic virus demonstrating its safety, ONYX-015 became the first virus to undergo clinical trials combined with chemotherapy.

Because oncolytic viruses were initially conceived of as local therapies, the first studies of ONYX-015 occurred in patients with recurrent head and neck carcinomas because of their poor prognosis, the tendency to succumb to local rather than metastatic disease, and the superficial readily accessible tumors, would be easily biopsied and would tolerate inflammation better than deeper cavities. Doses were safely escalated up to $2 \times 10^{12}$ viral particles (equivalent to approximately $10^{11}$ plaque-forming units (PFU)) daily 
for 5 consecutive days (Ganly et al., 2000). Viral DNA was demonstrated by in situ hybridization of tumor biopsies until 8 days postinoculation, indicating rapid viral clearance.

Subsequent intratumoral inoculation trials progressed to deeper, less-accessible tumors such as locally advanced pancreatic cancers and recurrent glioblastomas (Chiocca et al., 2004). Because of difficulties accessing these tumors, biopsy evidence for viral replication was not obtained on these trials.

Tumor types that spread within specific body cavities were felt to be appropriate targets for intracavitary inoculation. Therefore, intraperitoneal administration to patients with advanced refractory ovarian carcinoma was performed (Vasey et al., 2002), followed by intraesophageal instillation in patients with Barrett's esophagus. Finally, premalignant oral dysplasias were targeted through administration as a mouthwash (Rudin et al., 2003). Intraperitoneal administration proved to have dose-limiting toxicity at $10^{11} \mathrm{PFU}$ daily for 5 consecutive days. Viral genomes were detected in the peritoneum up to 15 days post-treatment but infection of tumor cells in ascitic fluid was not demonstrated. No objective responses were demonstrated.

Once preclinical studies suggested that intravenous adenovirus could inhibit the growth of established metastases (Heise et al., 1999), an appropriate clinical target for intravascularly administered adenovirus was sought. Colorectal carcinoma causes much of its morbidity and mortality through liver metastases, and these metastases receive over $90 \%$ of their blood supply from the hepatic artery. This led to the first trial of ONYX-015 administered through the hepatic artery for colorectal metastases to the liver. Safety was shown at doses up to $2 \times 10^{12}$ viral particles given on days $1,8,22$, 50 , and 78 , followed by a 5-fluorouracil (5-FU)-based chemotherapy regimen every 4 weeks (Reid et al., 2001). No major liver function abnormalities were observed. Viral replication was demonstrated in patients receiving the two highest doses by using PCR to detect an increase in genome concentrations in the blood. This was the first time oncolytic viral replication had been demonstrated in patients.

Intravenous ONYX-015 delivery was subsequently evaluated in patients with lung metastases (Nemunaitis et al., 2001). No dose-limiting toxicity was noted with doses up to $2 \times 10^{12}$ viral particles per injection.

\section{$H S V$}

Because of their known ability to replicate in neural tissue, oncolytic HSV were first tested in recurrent malignant glioma patients. Between 1997 and 1999, two groups performed phase I dose-escalation safety trials of replication-selective HSV 1716 and G207 in the treatment of malignant brain tumors. A Scottish group evaluated the $\gamma 34.5$ mutant 1716 in nine patients with brain tumors between 1997 and 1999 (Rampling et al., 2000), while a US group evaluated the double $\gamma 34.5$ and RR mutant G207 in 21 patients with brain tumors (Markert et al., 2000). Patients in the Scottish trial received lower doses of virus (between $10^{3}$ and $10^{5} \mathrm{PFU}$ ) than patients in the US trial (between $10^{6}$ and $\left.3 \times 10^{9} \mathrm{PFU}\right)$, based, in part, on the greater safety of double mutants demonstrated in animal models and the hypothesis of the Scottish group that viral replication effectively escalates any input dose.

In the 1716 trial, three patients each received $10^{3}, 10^{4}$, and $10^{5} \mathrm{PFU}$ of 1716 by a single intratumoral injection (Rampling et al., 2000). No adverse effects, including encephalitis, were seen that could be attributed to the administration of 1716. Five patients died of tumor progression at the conclusion of the 14-24-month study. The thallium SPECT volumes were smaller in one, stable in two, larger in five, and not assessable in one patient.

This same group followed that study with another study designed to verify viral replication in gliomas. In the second study, 12 patients with biopsy-proven highgrade glioma received an intratumoral dose of $10^{5} \mathrm{PFU}$ 1716 by stereotactic injection, with resection carried out 4-9 days later (Papanastassiou et al., 2002). In two patients, 1716 in excess of input dose was recovered from the injection site.

In the G207 trial, 21 patients received doses ranging from $10^{6} \mathrm{PFU}$ in a single site to $3 \times 10^{9} \mathrm{PFU}$ at five sites between 1998 and 1999 (Markert et al., 2000). Two patients had long-term expression of the $\beta$ galactosidase reporter gene found in G207 56 and 157 days after inoculation. No encephalitis was reported or found at autopsy. Four of the 21 patients were alive at the time the results were published. No deaths were attributable to the viral vector. Six of 21 patients had a decrease in the enhancement volume on MRI 1 month after viral inoculation (Markert et al., 2000).

HSV 1716 has also undergone a pilot study of intratumoral injection into subcutaneous nodules of metastatic melanoma in five patients with stage 4 melanoma, with a maximal dose of four injections of $10^{3} \mathrm{PFU}$ (MacKie et al., 2001). All patients who received two or more injections exhibited microscopic tumor necrosis with no viral replication outside of tumor cells, and one nodule exhibiting visible flattening.

Another herpes mutant, NV 1020 (R7020), which has deletions in one copy of $\gamma 34.5$, UL24, and UL56, has also been explored. The deleted region was replaced with a fragment of HSV-2 US DNA (US2, US3, gJ, and gG). The virus was originally developed as a herpes vaccine, but was unsuccessful. However, its safety profile in animal models led to a phase I study in treating nine patients with colorectal cancer metastatic to the liver by hepatic arterial infusion (Fong et al., 2002). No significant toxicity was noted at doses up to $10^{7} \mathrm{PFU}$, and viral gene expression was detected exclusively in tumor tissues. All patients showed reductions in serum CEA levels within 28 days of virus administration. At 28 days after virus administration, standard chemotherapy, the nature of which was unspecified, was initiated.

\section{Vaccinia}

In a phase I trial, four patients with invasive transitional cell carcinoma were given intravesical DryVax ${ }^{\circledR}$ vaccinia 
virus before radical cystectomy (Gomella et al., 2001). Treatment was well tolerated up to $10^{8} \mathrm{PFU} /$ injection. Infection was demonstrated by histology of bladder surgical specimen. Extensive inflammatory infiltrate was noted.

\section{Reovirus}

A phase I trial with reovirus (Reolysin ${ }^{\circledR}$ ) in cutaneous solid tumors by intralesional injections has been conducted by a Canadian group (Morris et al, 2002). The virus did not cause any dose-limiting toxicity with doses up to $10^{10} \mathrm{PFU} /$ injection. Overall response rate was $11 \%$, with another $45 \%$ showing stable disease.

\section{$N D V$}

NDV strain 73-T has been utilized in clinical trials as both a viral oncolysate, a suspension of virus and tumor cells that presumably acts as a tumor vaccine, and as free virus. A recent 15 -year follow-up of patients with stage III malignant melanoma treated postsurgically with 73-T oncolysate in 1975 as part of a phase II clinical study revealed a 55\% overall 15-year survival (Batliwalla et al., 1998). Investigators at Pro-Virus Inc. (Gaithersburg, MD, USA) isolated a naturally attenuated NDV strain, PV701, which they analysed in a phase I clinical trial in which patients with solid cancers who failed conventional therapy were treated with intravenous virus (Pecora et al., 2002). The maximum tolerated dose was $1.2 \times 10^{10} \mathrm{PFU} / \mathrm{m}^{2}$, with the most common dose-limiting toxicities being dyspnea, diarrhea, and dehydration. However, initial desensitization with a lower dose enabled subsequent dose escalation to $1.2 \times 10^{11} \mathrm{PFU} /$ $\mathrm{m}^{2}$ even when the second dose was given only 2 days later. The desensitization was thought to be due to the development of tolerance or tachyphylaxis to toxicity caused by the cytokine/acute phase responses mediated by IFN- $\alpha$, IFN- $\beta$, IFN- $\gamma$, TNF- $\alpha$, and IL- 6 . The overall response rate was $15 \%$, and time to tumor progression ranged from 4 to 30 months. There was one treatmentrelated death involving a 55-year-old man with renal carcinoma metastatic to the lungs and compromised pulmonary function as a result of previous lobectomies and an $8 \mathrm{~cm}$ metastasis in one of two remaining lung lobes. After an initial and only PV701 dose of $1.2 \times 10^{10} \mathrm{PFU} / \mathrm{m}^{2}$, fatal respiratory failure ensued. Post mortem revealed extensive inflammation limited to the tumor-bearing lung, suggestive that rapid tumor lysis had compromised the limited remaining respiratory function.

A subsequent trial utilized a slow $3 \mathrm{~h}$ viral infusion followed by $1 \mathrm{~h}$ infusions of subsequent doses (peaking again at $1.2 \times 10^{11} \mathrm{PFU} / \mathrm{m}^{2}$ ), causing an overall response rate of $28 \%$, with 11 of 18 patients having over 4 months of progression-free intervals (Hotte et al., 2003). Another NDV, OV 001, was successfully administered to six glioblastoma patients intravenously up to $10^{10} \mathrm{IU} /$ injection with no dose-limiting toxicity, NDV recovered from one biopsy, one patient with a near-complete response 30 weeks after start of viral administration, and one patient with stable disease maintained for 26 weeks (Freeman et al., 2004) (Table 2).

\section{Combination with conventional treatments}

\section{Radiation}

Because of the preclinical finding that radiation enhances the cytolytic effect of adenoviruses (Rogulski et al., 2000), there has been interest in combining radiation therapy with oncolytic viruses. The only published clinical trial reporting results of radiation therapy combined with an oncolytic virus was a phase I trial using replicating adenovirus, Ad5-CD/TK, which has an E1B deletion and carries a fusion gene expressing two prodrug-activating enzymes, Escherichia coli cytosine deaminase and HSV-TK. The prodrug-activating enzymes are described below. In the trial, a single intraprostatic injection of $10^{12}$ viral particles was given. After 2 days, patients were given the prodrugs 5-fluorocytosine and valganciclovir for varying amounts of time along with 70-74 Gy three-dimensional conformal radiation therapy (3D-CRT). A total of $44 \%$ of patients in the virus plus prodrug arm showed significant PSA reductions, whereas all patients in the virus plus prodrug plus radiation therapy arm showed significant PSA reductions (Freytag et al., 2003).

\section{Chemotherapy}

Because of synergy with cisplatin (Heise et al., 1997), adenovirus has been combined with cisplatin-based chemotherapy regimens in several clinical trials. The first ever clinical trial combining onocolytic virus with chemotherapy was initiated by (Khuri et al., 2000). A total of 37 patients with squamous cell carcinomas of the head and neck were given daily intratumoral injections of $10^{10} \mathrm{PFU}$ of d11520 for 5 consecutive days (Khuri et al., 2000). Cisplatin and 5-FU were then given simultaneously, with treatment cycles repeated every 3 weeks or until tumor grew or side effects were encountered. No toxicities beyond those seen with single agent treatment were reported. Out of 37 patients, 19 exhibited a response to treatment and only $15 \%$ of injected tumors had progressed 6 months after treatment initiation. More recently, a phase I/II trial was completed combining ONYX-015 administered intratumorally on days $1-5$ every month combined with MAP (mitomycin-C, doxorubicin, cisplatin) chemotherapy in six patients with advanced sarcoma (Galanis et al., 2005). Using a dose escalation from $10^{9} \mathrm{PFU} /$ dose up to $10^{10} \mathrm{PFU} /$ dose, adenoviral replication was detected in two of six patient biopsies on day 5 of the first cycle and a partial response lasting 11 months was achieved in one patient.

\section{Transcriptional targeting}

In an effort to enhance the selectivity of oncolytic viruses and increase their safety, several groups have placed key viral genes under the control of tumorselective promoters. This approach is best suited for an oncolytic virus that has been dose escalated to a 
Table 2 Summary of results from closed oncolytic virus clinical trials, as determined from published reports or data presented at meetings

\begin{tabular}{|c|c|c|c|c|c|c|c|c|c|c|c|c|c|c|}
\hline \multirow{2}{*}{$\begin{array}{l}\text { Phase/ } \\
\text { country }\end{array}$} & \multirow{2}{*}{$\begin{array}{l}\text { Tumor } \\
\text { type }\end{array}$} & \multirow{2}{*}{$\begin{array}{l}\text { Virus plus } \\
\text { chemotherapy } \\
\text { if used in trial }\end{array}$} & \multirow{2}{*}{ Viral dose } & \multirow[t]{2}{*}{ Route } & \multirow{2}{*}{$\begin{array}{l}\text { Number } \\
\text { of pa- } \\
\text { tients }\end{array}$} & \multicolumn{8}{|c|}{ Results } & \multirow[t]{2}{*}{ Ref. } \\
\hline & & & & & & $\begin{array}{l}\text { No. of patients } \\
\text { with response }\end{array}$ & $\begin{array}{l}\text { No. of patients } \\
\text { with tumor } \\
\text { Prgrsn }\end{array}$ & $T T P$ & Survival & $\begin{array}{l}\text { Viral } \\
\text { genes }\end{array}$ & Shed virus & $A b$ & $\begin{array}{l}\text { Grade } 3 \text { or } 4 \\
\text { adverse events }\end{array}$ & \\
\hline \multicolumn{15}{|c|}{ Adenovirus } \\
\hline $\mathrm{I} / \mathrm{UK}$ & HNSCC & ONYX-015 & $10^{7}-10^{11} \mathrm{PFU}$ & i.t. & 22 & $5 / 22(23 \%)$ & $9 / 22(41 \%)$ & $\mathrm{N} / \mathrm{S}$ & $\mathrm{N} / \mathrm{S}$ & $\begin{array}{l}4 / 22 \text { by } \\
\text { ISH }\end{array}$ & $\begin{array}{l}\text { None (blood, } \\
\text { oral swab) }\end{array}$ & $21 / 22$ & None & $\begin{array}{l}\text { Ganly et al. } \\
(2000)\end{array}$ \\
\hline II/USA & HNSCC & ONYX-015 & $\begin{array}{l}10^{10} \mathrm{PFU} \text { q.d. } \times 5 \\
\text { days }-10^{10} \mathrm{PFU} \\
\text { b.i.d. } \times 10 \text { days }\end{array}$ & i.t. & 37 & $8 / 24(33 \%)$ & $7 / 24(29 \%)$ & 51 days & $\mathrm{N} / \mathrm{S}$ & $\begin{array}{l}7 / 11 \text { by } \\
\text { ISH }\end{array}$ & $\mathrm{N} / \mathrm{S}$ & $37 / 37$ & None & $\begin{array}{l}\text { Nemunaitis } \\
\text { et al. (2000) }\end{array}$ \\
\hline II/USA & HNSCC & ONYX-015 & $\begin{array}{l}2 \times 10^{11} \text { vp q.d. } \times 5 \\
\text { or b.i.d. } \times 14\end{array}$ & i.t. & 40 & $8 / 36(22 \%)$ & $15 / 36(42 \%)$ & $\mathrm{N} / \mathrm{S}$ & $\mathrm{N} / \mathrm{S}$ & $\mathrm{N} / \mathrm{S}$ & $\begin{array}{l}\text { Serum PCR: } \\
\text { 12/29 (cycle } 1) ; \\
6 / 21 \text { (cycle } 2) ; \\
2 / 8(\text { cycle } 3)\end{array}$ & $\begin{array}{l}40 / 40 \text { after } \\
; \text { cycle } 2\end{array}$ & $\begin{array}{l}33 \text { grade } 3 \text { and } 5 \\
\text { grade } 4 \text { adverse } \\
\text { events }\end{array}$ & $\begin{array}{l}\text { Nemunaitis } \\
\text { et al. (2001) }\end{array}$ \\
\hline I/USA & Pancreas & ONYX-015 & $\begin{array}{l}\text { Dose escalation } \\
\text { from } 10^{8} \text { to } 10^{11} \\
\text { PFU }\end{array}$ & i.t. & 23 & $6 / 22(27 \%)$ & $5 / 22(23 \%)$ & $\mathrm{N} / \mathrm{S}$ & $\mathrm{N} / \mathrm{S}$ & $\begin{array}{l}0 / 22 \text { by } \\
\text { ISH of } b x\end{array}$ & $\begin{array}{l}0 / 22 \text { by serum } \\
\text { PCR after } \\
\text { day } 1\end{array}$ & $\begin{array}{l}22 / 22 \text { after } \\
\text { cycle } 1\end{array}$ & $\begin{array}{l}\text { Grade } 4-4 \% \text { of } \\
\text { patients (leukopenia); } \\
\text { grade } 3-43 \% \text { of } \\
\text { patients ( } 22 \% \text { asthenia, } \\
4 \% \text { nausea, } 4 \% \\
\text { malaise, } 9 \% \text { pain, } \\
4 \% \text { hypertension) }\end{array}$ & $\begin{array}{l}\text { Mulvihill } \\
\text { et al. (2001) }\end{array}$ \\
\hline I/USA & GBM & ONYX-015 & $10^{7}-10^{10} \mathrm{PFU}$ & i.t. & 24 & $0 / 24$ & $23 / 24(96 \%)$ & $\mathrm{N} / \mathrm{S}$ & $\begin{array}{l}\text { Median } \\
4.9 \text { months } \\
\text { (GBM) } \\
11.3 \\
\text { months } \\
\text { (AA and } \\
\text { AO) }\end{array}$ & $\mathrm{N} / \mathrm{S}$ & $\mathrm{N} / \mathrm{S}$ & $2 / 24$ & $\begin{array}{l}21 \text { grade } 3 / 4 \text { adverse } \\
\text { events; } 10 / 24 \text { patients } \\
\text { had one or more } \\
\text { grade } 3 / 4 \text { adverse } \\
\text { events }\end{array}$ & $\begin{array}{l}\text { Chiocca } \\
\text { et al. (2004) }\end{array}$ \\
\hline II/UK & Oral SCC & ONYX-015 & $10^{10} \mathrm{PFU}$ & i.t. & 15 & $\mathrm{~N} / \mathrm{S}$ & $\mathrm{N} / \mathrm{S}$ & $\mathrm{N} / \mathrm{S}$ & $\mathrm{N} / \mathrm{S}$ & $\begin{array}{l}2 / 15 \text { by } \\
\text { ISH; } 8 / 15 \\
\text { by IHC }\end{array}$ & $\mathrm{N} / \mathrm{S}$ & $\mathrm{N} / \mathrm{S}$ & $\mathrm{N} / \mathrm{S}$ & $\begin{array}{l}\text { Morley } \\
\text { et al. (2004) }\end{array}$ \\
\hline II/USA & $\begin{array}{l}\text { Hepato- } \\
\text { biliary }\end{array}$ & ONYX-015 & $\begin{array}{l}6 \times 10^{9}-3 \times 10^{10} \\
\text { PFU }\end{array}$ & i.t. & 19 & $\begin{array}{l}8 / 16 \text { AFP } \downarrow \\
(50 \%)\end{array}$ & $3 / 16(19 \%)$ & $\mathrm{N} / \mathrm{S}$ & $\mathrm{N} / \mathrm{S}$ & $\begin{array}{l}2 / 2 \text { bile } \\
\text { stent } \\
\text { PCR }^{+} 4 / 4 \\
\text { ascites } \\
\text { PCR }^{+}\end{array}$ & $\begin{array}{l}0 / 14 \text { by PCR } \\
\text { of blood, urine }\end{array}$ & $e^{16 / 16}$ & 4 grade $3 ; 2$ grade 4 & $\begin{array}{l}\text { Makower } \\
\text { et al. (2003) }\end{array}$ \\
\hline I/UK & Ovarian & ONYX-015 & $\begin{array}{l}10^{9}-10^{11} \mathrm{PFU} \\
\text { q.d. } \times 5\end{array}$ & i.p. & 16 & $1 / 16$ CA125 $\downarrow$ & $14 / 16(88 \%)$ & $\mathrm{N} / \mathrm{S}$ & $\mathrm{N} / \mathrm{S}$ & $\begin{array}{l}7 / 8 \text { perito- } \\
\text { neal wash } \\
\text { PCR }^{+}\end{array}$ & $\begin{array}{l}0 / 8 \text { serum } \\
\mathrm{PCR}^{+}\end{array}$ & $16 / 16$ & 1 grade 3 & $\begin{array}{l}\text { Vasey et al. } \\
(2002)\end{array}$ \\
\hline II/UK & $\mathrm{HCC}$ & ONYX-015 & $\begin{array}{l}\text { (1) Control group: } \\
\text { precutaneous } \\
\text { ethanol; (2) ONYX } \\
\text { group }-3 \times 10^{11} \\
\text { PFU day } 1 \text { i.v., } \\
\text { then i.t. on days } \\
2,15,16,29,30\end{array}$ & $\begin{array}{l}\text { i.v., } \\
\text { then } \\
\text { i.t. }\end{array}$ & $\begin{array}{l}10(5 \\
\text { control, } \\
5 \\
\text { ONYX- } \\
015)\end{array}$ & $1 / 5$ AFP $\downarrow$ & $4 / 5(80 \%)$ & $\mathrm{N} / \mathrm{S}$ & $\mathrm{N} / \mathrm{S}$ & $5 / 5$ by EM & $\begin{array}{l}\text { None by } \\
\text { blood PCR } \\
\text { at } 4 \mathrm{~h}\end{array}$ & $5 / 5$ & None & $\begin{array}{l}\text { Habib et al. } \\
(2002)\end{array}$ \\
\hline II/USA & $\begin{array}{l}\text { Metastatic } \\
\text { CRC }\end{array}$ & ONYX-015 & $\begin{array}{l}2 \times 10^{12} \text { vp days } 1 \\
15 / \mathrm{q} 28 \mathrm{~d} \times 6 \text { cycles }\end{array}$ & i.v. & 18 & $4 / 18$ CEA $\downarrow$ & $11 / 18(61 \%)$ & $\mathrm{N} / \mathrm{S}$ & $\mathrm{N} / \mathrm{S}$ & $\mathrm{N} / \mathrm{S}$ & $\begin{array}{l}5 / 18 \text { blood } \\
\text { PCR }^{+}\end{array}$ & $15 / 15$ & $\begin{array}{l}3 \text { grade } 3 \text { events } \\
\text { (fatigue, fever, } \\
\text { diarrhea); no grade } \\
4 \text { events }\end{array}$ & $\begin{array}{l}\text { Hamid et al. } \\
\text { (2003) }\end{array}$ \\
\hline II/USA & HNSCC & $\begin{array}{l}\text { ONYX- } \\
015+\text { cispla- } \\
\text { tin }+5-\mathrm{FU}\end{array}$ & $\begin{array}{l}\text { Each cycle }=\left(10^{10} \mathrm{PFU}\right. \\
\text { q.d. } \times 5 \text { days }+ \text { cisplatin } \\
80 \mathrm{mg} / \mathrm{m}^{2} \text { i.v. on day }\end{array}$ & i.t. & 37 & $19 / 37(53 \%)$ & $\begin{array}{l}5 / 30 \text { at } 6 \\
\text { months }(17 \%)\end{array}$ & $\begin{array}{l}\text { Median } \\
120 \text { days }\end{array}$ & $\begin{array}{l}\text { Median } \\
10.5 \\
\text { months }\end{array}$ & $\begin{array}{l}3 / 5 \text { on } \\
\text { day } 5 ; 2 / 5\end{array}$ & $\mathrm{~N} / \mathrm{S}$ & $37 / 37$ & $\begin{array}{l}17 / 37(46 \%) \text { patients } \\
\text { had grade } 3 \text { events; }\end{array}$ & $\begin{array}{l}\text { Khuri et al. } \\
(2000)\end{array}$ \\
\hline
\end{tabular}


Table 2 (Continued)

\begin{tabular}{|c|c|c|c|c|c|c|c|c|c|c|c|c|c|c|}
\hline \multirow{2}{*}{$\begin{array}{l}\text { Phase/ } \\
\text { country }\end{array}$} & \multirow{2}{*}{$\begin{array}{l}\text { Tumor } \\
\text { type }\end{array}$} & \multirow{2}{*}{$\begin{array}{l}\text { Virus plus } \\
\text { chemotherapy } \\
\text { if used in trial }\end{array}$} & \multirow{2}{*}{ Viral dose } & \multirow[t]{2}{*}{ Route } & \multirow{2}{*}{$\begin{array}{l}\text { Number } \\
\text { of pa- } \\
\text { tients }\end{array}$} & \multicolumn{8}{|c|}{ Results } & \multirow[t]{2}{*}{ Ref. } \\
\hline & & & & & & $\begin{array}{l}\text { No. of patients } \\
\text { with response }\end{array}$ & $\begin{array}{l}\text { No. of patients } 7 \\
\text { with tumor } \\
\text { Prgrsn }\end{array}$ & $T T P$ & Survival & $\begin{array}{l}\text { Viral } \\
\text { genes }\end{array}$ & Shed virus & $A b$ & $\begin{array}{l}\text { Grade } 3 \text { or } 4 \\
\text { adverse events }\end{array}$ & \\
\hline & & & $\begin{array}{l}1+800-1000 \mathrm{mg} / \mathrm{m}^{2} \\
5 \text {-FU q.d. } \times 5 \text { days); } \\
\text { cycle repeated every } \\
3 \text { weeks }\end{array}$ & & & & & & & $\begin{array}{l}\text { on day } 15 \\
\text { by ISH }\end{array}$ & & & $\begin{array}{l}5 / 37(14 \%) \text { had } \\
\text { grade } 4 \text { events }\end{array}$ & \\
\hline I-II/USA & Pancreas & $\begin{array}{ll}\text { ONYX- } & \\
015+\text { gemci- } & 1 \\
\text { tabine } & 5 \\
& 1 \\
& 1 \\
& 3\end{array}$ & $\begin{array}{l}\text { ONYX- } 015 \text { days } \\
1,5,8,15,36,43 \\
50,57: 2 \times 10^{10}-2 \times \\
10^{11} \mathrm{PFU} ; \text { gemcitabine: } \\
1000 \mathrm{mg} / \mathrm{m}^{2} \text { on days } \\
36,43,50,57\end{array}$ & i.t. & $\begin{array}{l}6 \text { (phase } \\
\text { I); } 15 \\
\text { (phase } \\
\text { II) }\end{array}$ & $\begin{array}{l}\text { Partial re- } \\
\text { sponse in } \\
2 / 21(10 \%)\end{array}$ & $11 / 21(52 \%)$ & $\begin{array}{l}\text { Median } 6 \\
\text { weeks }\end{array}$ & $\begin{array}{l}\text { Median } 7 . \\
\text { months }\end{array}$ & $\begin{array}{l}5 \mathrm{None} \\
\text { by ISH }\end{array}$ & $\mathrm{N} / \mathrm{S}$ & $21 / 21$ & 21 grade $3 / 4$ events & $\begin{array}{l}\text { Hecht et al. } \\
\text { (2003) }\end{array}$ \\
\hline I-II/USA & $\begin{array}{l}\text { Advanced } \\
\text { sarcoma }\end{array}$ & $\begin{array}{l}\text { ONYX- } \\
015+\text { doxo- } \\
\text { rubicin }+ \\
\text { cisplatin }\end{array}$ & $\begin{array}{l}10^{9}-10^{10} \mathrm{PFU} / \text { cycle } \\
\text { for } 1-6 \text { cycles }\end{array}$ & i.t. & 6 & $1 / 6$ & $1 / 6$ & $\begin{array}{l}\text { Median } 2 \\
\text { months }\end{array}$ & $\mathrm{N} / \mathrm{S}$ & $\begin{array}{l}2 / 4 \text { by } \\
\text { ISH }\end{array}$ & $\begin{array}{l}\text { Blood } \mathrm{PCR}^{+} \\
\text {in all at day } \\
5 \text { after highest } \\
\text { dose }\end{array}$ & $6 / 6$ & $\begin{array}{l}8 \text { grade } 3 \text { events; } \\
7 \text { grade } 4 \text { events }\end{array}$ & $\begin{array}{l}\text { Galanis et al. } \\
\text { (2005) }\end{array}$ \\
\hline $\begin{array}{l}\text { I-II/UK, } \\
\text { Egypt }\end{array}$ & Liver & $\begin{array}{lr}\text { ONYX- } & \text { I } \\
015+5-\mathrm{FU}+\mathrm{f} \\
\text { oxaleplatin } & 3 \\
& \mathrm{r}\end{array}$ & $\begin{array}{l}\text { Dose escalation } \\
\text { from } 3 \times 10^{9} \text { to } \\
3 \times 10^{11} \mathrm{PFU} \\
\text { regardless of route }\end{array}$ & $\begin{array}{l}\text { i.t., } \\
\text { h.a.i., } \\
\text { i.v. }\end{array}$ & $\begin{array}{l}16(9 \\
\text { phase I, } \\
7 \text { phase } \\
\text { II) }\end{array}$ & $\begin{array}{l}\downarrow \text { CEA in } \\
4 / 7 \text { phase II } \\
\text { patients }\end{array}$ & $\begin{array}{l}1 / 7 \text { phase II } \\
\text { cases by CT }\end{array}$ & $\mathrm{N} / \mathrm{S}$ & $\mathrm{N} / \mathrm{S}$ & $\begin{array}{l}16 / 16 \text { by } \\
\text { EM at } \\
14 \text { days }\end{array}$ & $\mathrm{N} / \mathrm{S}$ & $\mathrm{N} / \mathrm{S}$ & None & $\begin{array}{l}\text { Habib et al. } \\
\text { (2001) }\end{array}$ \\
\hline I/USA & $\begin{array}{l}\text { CRC liver } \\
\text { mets }\end{array}$ & $\begin{array}{l}\text { ONYX- } \\
015+5-\mathrm{FU}\end{array}$ & $\begin{array}{l}2 \times 10^{8}-2 \times 10^{12} \mathrm{vp} \\
\text { q.d. on days } 1,8, \\
22,50,78+5-\mathrm{FU} \\
425 \mathrm{mg} / \mathrm{m}^{2} \text { i.v. q.d. } \\
\text { on days } 22,50,78\end{array}$ & h.a.i. & 11 & $\begin{array}{l}1 / 11 \text { (patient } \\
\text { received } \\
\text { high dose) }\end{array}$ & $\begin{array}{l}0 / 3 \text { at high } \\
\text { dose }\left(2 \times 10^{8}-\right. \\
\left.6 \times 10^{11} \mathrm{vp}\right) ; \mathrm{N} / \\
\mathrm{S} \text { for low dose }\end{array}$ & $\mathrm{N} / \mathrm{S}$ & $\mathrm{N} / \mathrm{S}$ & $\begin{array}{l}\text { CPE in } \\
0 / 11\end{array}$ & $\begin{array}{l}\text { Day 4: none } \\
\text { in blood PCR } \\
\text { of all at doses } \\
<2 \times 10^{11} \mathrm{vp} ; \\
\text { all } \mathrm{PCR}^{+} \text {at } \\
\text { doses } \\
\geqslant 2 \times 10^{11} \mathrm{vp}\end{array}$ & $11 / 11$ & $\begin{array}{l}24 \text { grade } 3 \text { events; } \\
\text { no grade } 4 \text { events }\end{array}$ & $\begin{array}{l}\text { Reid et al. } \\
\text { (2001) }\end{array}$ \\
\hline II/USA & $\begin{array}{l}\text { CRC liver } \\
\text { mets }\end{array}$ & $\begin{array}{l}\text { ONYX- } \\
015+5-\mathrm{FU}\end{array}$ & $\begin{array}{l}2 \times 10^{12} \text { vp q.d. on days } 1 \\
1,8,22,50,78+5 \text {-FU } \\
425 \mathrm{mg} / \mathrm{m}^{2} \text { i.v. q.d. on } \\
\text { days } 22,50,78\end{array}$ & h.a.i. & 27 & $\begin{array}{l}3 / 27 \text { partial } \\
\text { response } \\
(11 \%), 4 / 27 \\
\text { MR }(15 \%)\end{array}$ & $11 / 27(41 \%)$ & $\mathrm{N} / \mathrm{S}$ & $\mathrm{N} / \mathrm{S}$ & $\mathrm{N} / \mathrm{S}$ & $\begin{array}{l}6 / 8 \mathrm{PCR}^{+} \\
\text {blood }\end{array}$ & $\mathrm{N} / \mathrm{S}$ & $\begin{array}{l}5 \text { grade } 3 \text { events } \\
\text { (bilirubinemia; transa- } \\
\text { minitis); all patients } \\
\text { with flu-like sx }\end{array}$ & $\begin{array}{l}\text { Reid et al. } \\
(2002)\end{array}$ \\
\hline I/USA & Lung mets & $\begin{array}{l}\text { ONYX- } \\
015 \pm \\
\text { chemo } \\
\text { (carbopla- } \\
\text { tin + taxol) }\end{array}$ & $\begin{array}{l}2 \times 10^{10}-2 \times 10^{13} \mathrm{vp} / \\
\text { week } \times 6 \text { weeks } \\
\text { chemo }\left(80 \mathrm{mg} / \mathrm{m}^{2}\right. \\
\text { taxol i.v. q.d. } \times 1 \\
\text { week }+ \text { carboplatin ANC } \\
\text { of } 2 \text { i.v. q.d. } \\
\times 1 \text { week })\end{array}$ & i.v. & 10 & $1 / 10(10 \%)$ & $1 / 10(10 \%)$ & $\begin{array}{l}\text { Median } 91 \\
\text { days }\end{array}$ & $\begin{array}{l}\text { Median } \\
298 \text { days }\end{array}$ & $\begin{array}{l}1 / 1 \text { by } \\
\text { IHC }\end{array}$ & $\begin{array}{l}\text { Plasma PCR } \text { PC }^{+} \\
\text {in } 17 / 37(46 \%) \\
\text { cycle } 1 \text { and } 8 / \\
21(38 \%) \text { cycle } \\
2\end{array}$ & $10 / 10$ & $\begin{array}{l}7 \text { grade } 3 \text { events in } \\
4 \text { patients; } 2 \text { grade } \\
4 \text { events in } 1 \text { patient }\end{array}$ & $\begin{array}{l}\text { Nemunaitis } \\
\text { et al. (2001) }\end{array}$ \\
\hline I/USA & Metastatic & $\begin{array}{l}\text { ONYX-015 } \\
\text { plus chemo } \\
\text { (CPT-11+5- v } \\
\text { FU) or cyto- v } \\
\text { kine (IL-2) } \\
\\
\text { s } \\
\text { v }\end{array}$ & $\begin{array}{l}\text { Group } 1-\left(2 \times 10^{12}\right. \\
\text { vp qw }+ \text { CPT- } 11125 \mathrm{mg} / \\
\text { week }+5 \text {-FU } 500 \mathrm{mg} / \\
\text { week }) \times 6 \text { weeks; group } 2 \\
-2 \times 10^{11} \mathrm{vp} \mathrm{qw} \times 6 \\
\text { weeks }+1.1 \times 10^{6} \mathrm{U} \text { IL-2 } \\
\text { s.c. } 5 \text { days } / \text { week } \times 4 \\
\text { weeks }\end{array}$ & i.v. & 10 & $0 / 9(0 \%)$ & $5 / 9(56 \%)$ & $\begin{array}{l}\text { Median } 39 \\
\text { days }\end{array}$ & $\begin{array}{l}\text { Median } \\
251 \text { days }\end{array}$ & $\begin{array}{l}3 / 3 \text { by } \\
\text { PCR of } \\
\text { bx; } 1 / 3 \\
\text { by EM }\end{array}$ & $\begin{array}{l}3 / 10 \mathrm{PCR}^{+} \\
\text {blood } 48 \mathrm{~h}\end{array}$ & $10 / 10$ & $\begin{array}{l}3 \text { grade } 3 \text { events } \\
\text { in } 2 \text { patients; } \\
1 \text { grade } 4 \text { event } \\
\text { in } 1 \text { patient }\end{array}$ & $\begin{array}{l}\text { Nemunaitis } \\
\text { et al. }(2003)\end{array}$ \\
\hline I/USA & Prostate & $\begin{array}{l}\text { CV706 (PSA 1 } \\
\text { driven } \\
\text { E1A, i } \\
\text { E3-deleted) }\end{array}$ & $\begin{array}{l}10^{11}-10^{13} \mathrm{PFU} \text { per } \\
\text { injection (multiple } \\
\text { injections given) }\end{array}$ & i.t. & 20 & $\begin{array}{l}\downarrow \text { PSA } \geqslant 30 \% \\
\text { in } 13 / 20 ; 4 / 20 \\
(20 \%) \text { with } \\
\text { partial re- } \\
\text { sponse }(\downarrow\end{array}$ & $\mathrm{N} / \mathrm{S}$ & $\mathrm{N} / \mathrm{S}$ & $\mathrm{N} / \mathrm{S}$ & $\begin{array}{l}20 / 20 \text { by } \\
\text { IHC }\end{array}$ & $\begin{array}{l}14 / 16 \text { blood } \\
\text { PCR }^{+} \text {at } \\
30 \mathrm{~min} ; 13 / 16 \\
\text { blood } \text { PCR }^{+}\end{array}$ & $20 / 20$ & $\begin{array}{l}5 \text { grade } 3 \text { events } \\
\text { in } 5 \text { patients; } \\
\text { no grade } 4 \text { events }\end{array}$ & $\begin{array}{l}\text { DeWeese et al. } \\
\text { (2001) }\end{array}$ \\
\hline
\end{tabular}


Table 2 (Continued)

\begin{tabular}{|c|c|c|c|c|c|c|c|c|c|c|c|c|c|c|}
\hline \multirow{2}{*}{$\begin{array}{l}\text { Phase/ } \\
\text { country }\end{array}$} & \multirow{2}{*}{$\begin{array}{l}\text { Tumor } \\
\text { type }\end{array}$} & \multirow{2}{*}{$\begin{array}{l}\text { Virus plus } \\
\text { chemotherapy } \\
\text { if used in trial }\end{array}$} & \multirow{2}{*}{ Viral dose } & \multirow[t]{2}{*}{ Route } & \multirow{2}{*}{$\begin{array}{l}\text { Number } \\
\text { of pa- } \\
\text { tients }\end{array}$} & \multicolumn{8}{|c|}{ Results } & \multirow[t]{2}{*}{ Ref. } \\
\hline & & & & & & $\begin{array}{l}\text { No. of patients } \\
\text { with response }\end{array}$ & $\begin{array}{l}\text { No. of patients } \\
\text { with tumor } \\
\text { Prgrsn }\end{array}$ & $T T P$ & Survival & $\begin{array}{l}\text { Viral } \\
\text { genes }\end{array}$ & Shed virus & $A b$ & $\begin{array}{l}\text { Grade } 3 \text { or } 4 \\
\text { adverse events }\end{array}$ & \\
\hline & & & & & & \multicolumn{5}{|c|}{$\begin{array}{l}\mathrm{PSA} \geqslant 50 \% \text { for } \\
4 \text { weeks) }\end{array}$} & \multicolumn{3}{|l|}{$\begin{array}{l}2-8 \text { days after } \\
\text { treatment }\end{array}$} & \\
\hline I/China & Solid & $\begin{array}{l}\text { H101 (E1B- } \\
\text { deleted) }\end{array}$ & $5 \times 10^{7}-1.5 \times 10^{12} \mathrm{vp}$ & i.t. & 15 & $\mathrm{~N} / \mathrm{S}$ & $\mathrm{N} / \mathrm{S}$ & $\mathrm{N} / \mathrm{S}$ & $\mathrm{N} / \mathrm{S}$ & $\mathrm{N} / \mathrm{S}$ & $\begin{array}{l}15 / 15 \text { blood } \\
\text { PCR }^{+}\end{array}$ & $\mathrm{N} / \mathrm{S}$ & None & $\begin{array}{l}\text { Yuan et al. } \\
\text { (2003) }\end{array}$ \\
\hline I/USA & Prostate & $\mathrm{Ad} 5-\mathrm{CD} / \mathrm{TK}$ & $\begin{array}{l}10^{10}-10^{12} \mathrm{vp} \text { day } 1 \\
150 \mathrm{mg} / \mathrm{kg} / \text { day } 5- \\
\mathrm{FC}+10 \mathrm{mg} / \mathrm{kg} / \text { day } \\
\text { GCV days } 3-9\end{array}$ & i.t. & 16 & $\begin{array}{l}\downarrow \text { PSA } \geqslant 25 \% \\
\text { in } 7 / 16 ; 3 / 16 \\
\text { with partial } \\
\text { response }(\downarrow \\
\text { PSA } \geqslant 50 \% \\
\text { for } 4 \text { weeks) }\end{array}$ & $\mathrm{N} / \mathrm{S}$ & $\mathrm{N} / \mathrm{S}$ & $\mathrm{N} / \mathrm{S}$ & $\begin{array}{l}4 / 12 \text { by } \\
\text { IHC at } 2 \\
\text { weeks }\end{array}$ & $\begin{array}{l}\text { No infectious } \\
\text { virus in any } \\
\text { urine or blood } \\
\text { by PCR }\end{array}$ & $16 / 16$ & $\begin{array}{l}9 \text { grade } 3 \text { events; } \\
\text { no grade } 4 \text { events }\end{array}$ & $\begin{array}{l}\text { Freytag et al. } \\
(2002)\end{array}$ \\
\hline I/USA & Prostate & Ad5-CD/TK & $\begin{array}{l}10^{12} \text { vp day } 1 ; 5- \\
\text { FC+ valganciclovir } \\
\text { for } 1-3 \text { weeks }\end{array}$ & i.t. & 15 & $\begin{array}{l}15 / 15 \text { with } \downarrow \\
\text { PSA; } 4 / 6 \\
(67 \%) \text { negative } \\
\text { for adenocarci- } \\
\text { noma at } 1 \text { year }\end{array}$ & N/S & $\mathrm{N} / \mathrm{S}$ & $\mathrm{N} / \mathrm{S}$ & $\begin{array}{l}3 / 3 \text { by } \\
\text { IHC at } \\
2 \text { weeks; } \\
1 / 3 \text { at } 3 \\
\text { weeks; } 0 / 3 \\
\text { at } 4 \text { weeks }\end{array}$ & $\begin{array}{l}\text { No infectious } \\
\text { virus in blood } \\
\text { at any point }\end{array}$ & $\mathrm{N} / \mathrm{S}$ & $\begin{array}{l}11 \text { grade } 3 \text { events; } \\
\text { no grade } 4 \text { events }\end{array}$ & $\begin{array}{l}\text { Freytag et al. } \\
(2003)\end{array}$ \\
\hline II/China & Solid & $\begin{array}{l}\text { H101 (E1B- } \\
\text { deleted) }\end{array}$ & $\begin{array}{l}5 \times 10^{11} \text { vp q.d. } \times 5 \\
\text { days every } 3 \\
\text { weeks } \times 1-5 \text { week- } \\
\mathrm{s}+\text { chemo (drugs and } \\
\text { doses } \mathrm{N} / \mathrm{S} \text { ) }\end{array}$ & i.t. & 50 & $14 / 46(30 \%)$ & $8 / 46(17 \%)$ & $\mathrm{N} / \mathrm{S}$ & $\mathrm{N} / \mathrm{S}$ & $\mathrm{N} / \mathrm{S}$ & $\mathrm{N} / \mathrm{S}$ & $\mathrm{N} / \mathrm{S}$ & None & Xu et al. (2003) \\
\hline \multicolumn{15}{|l|}{$H S V-1$} \\
\hline I/USA & GBM & $\begin{array}{l}\text { G207 } \\
\left(\mathrm{ICP} 6^{-}\right. \\
\left.\gamma 34.5^{-}\right)\end{array}$ & $10^{6}-3 \times 10^{9} \mathrm{PFU}$ & i.t. & 21 & $0 / 21$ & $21 / 21$ & $\begin{array}{l}\text { Mean } 3.5 \\
\text { months }\end{array}$ & $\begin{array}{l}\text { Mean } \\
15.9 \\
\text { months } \\
(\text { GBM }) \\
\text { mean } 40.5 \\
\text { months } \\
\text { (AA) }\end{array}$ & $\begin{array}{l}2 / 6 \text { by } \\
\text { PCR } \\
\text { of } b x\end{array}$ & $\begin{array}{l}0 / 21 \text { by } \\
\text { saliva } \\
\text { culture }\end{array}$ & $\begin{array}{l}14 / 19 \text { with } \\
\text { HSV anti- } \\
\text { body at } \\
\text { start; } 15 / 19 \\
\text { at end }\end{array}$ & No & $\begin{array}{l}\text { Markert et al. } \\
(2000)\end{array}$ \\
\hline I/UK & Melanoma & $1716\left(\gamma 34.5^{-}\right)$ & $10^{5} \mathrm{PFU}$ & i.t. & 5 & $\begin{array}{l}1 / 5 \text { with flat- } \\
\text { tened nodule }\end{array}$ & $0 / 5$ & $\mathrm{~N} / \mathrm{S}$ & $\mathrm{N} / \mathrm{S}$ & $\begin{array}{l}5 / 5 \text { by } \\
\text { IHC }\end{array}$ & $\begin{array}{l}0 / 5 \text { serum } \\
\mathrm{PCR}^{+}\end{array}$ & $\begin{array}{l}5 / 5 \text { sero- } \\
\text { positive at } \\
\text { start; no } \uparrow \\
\text { in titer }\end{array}$ & No & $\begin{array}{l}\text { MacKie } e t a l . \\
(2001)\end{array}$ \\
\hline $\mathrm{I} / \mathrm{UK}$ & $\begin{array}{l}\text { Cutaneous } \\
\text { and subcu- } \\
\text { taneous me- } \\
\text { tastases }\end{array}$ & $\begin{array}{l}\text { Onco-VEX } \\
\left(\gamma 34.5^{-}\right. \\
-\mathrm{ICP}^{-} 7^{-} \\
\left.\mathrm{GM}^{-\mathrm{CSF}^{+}}\right)\end{array}$ & $10^{6}-10^{7} \mathrm{PFU}$ & i.t. & 8 & $\mathrm{~N} / \mathrm{S}$ & $\mathrm{N} / \mathrm{S}$ & $\mathrm{N} / \mathrm{S}$ & $\mathrm{N} / \mathrm{S}$ & $\mathrm{N} / \mathrm{S}$ & $\begin{array}{l}3 / 8 \text { by PCR } \\
\text { of blood, } \\
\text { urine }\end{array}$ & $\mathrm{N} / \mathrm{S}$ & $\mathrm{N} / \mathrm{S}$ & Hu et al. (2003) \\
\hline I/UK & GBM & $1716\left(\gamma 34.5^{-}\right)$ & $10^{5} \mathrm{PFU}$ & i.t. & 12 & $2 / 12(17 \%)$ & $10 / 12(83 \%)$ & $\mathrm{N} / \mathrm{S}$ & $\begin{array}{l}3 / 12 \text { alive } \\
\text { at } 15,18, \\
22 \text { months } \\
\text { postop }\end{array}$ & $\begin{array}{l}\text { Not } \\
\text { given }\end{array}$ & $\begin{array}{l}4 / 12 \text { serum }^{+} \\
\text {(3 with prior } \\
\text { HSV } \\
\text { infection) }\end{array}$ & $2 / 3 \operatorname{IgM}$ & No & $\begin{array}{l}\text { Harrow et al. } \\
\text { (2004) }\end{array}$ \\
\hline II/UK & GBM & $1716\left(\gamma 34.5^{-}\right)$ & $10^{5} \mathrm{PFU}$ & i.t. & 12 & $\mathrm{~N} / \mathrm{S}$ & $\mathrm{N} / \mathrm{S}$ & $\mathrm{N} / \mathrm{S}$ & $\mathrm{N} / \mathrm{S}$ & $\begin{array}{l}2 / 12 \text { had } \\
\text { HSV in } \\
\text { bx greater } \\
\text { than input } \\
\text { dose } 2 / 12 \\
\text { by IHC }\end{array}$ & $\begin{array}{l}1 / 12 \mathrm{PCR}^{+} \\
\text {in blood }\end{array}$ & $5 / 12$ & No & $\begin{array}{l}\text { Papanastassiou } \\
\text { et al. }(2002)\end{array}$ \\
\hline I/USA & & & $1.3 \times 10^{6}-1.3 \times 10^{7} \mathrm{PFU}$ & h.a.i. & 9 & & $0 / 9$ & $\mathrm{~N} / \mathrm{S}$ & & $\mathrm{N} / \mathrm{S}$ & & $\mathrm{N} / \mathrm{S}$ & & \\
\hline
\end{tabular}


Table 2 (Continued)

\begin{tabular}{|c|c|c|c|c|c|c|c|c|c|c|c|c|c|c|}
\hline \multirow{3}{*}{$\begin{array}{l}\text { Phase/ } \\
\text { country }\end{array}$} & \multirow{2}{*}{$\begin{array}{l}\text { Tumor } \\
\text { type }\end{array}$} & \multirow{2}{*}{$\begin{array}{l}\text { Virus plus } \\
\text { chemotherapy } \\
\text { if used in trial }\end{array}$} & \multirow{2}{*}{ Viral dose } & \multirow[t]{2}{*}{ Route } & \multirow{2}{*}{$\begin{array}{l}\text { Number } \\
\text { of pa- } \\
\text { tients }\end{array}$} & \multicolumn{8}{|c|}{ Results } & \multirow[t]{2}{*}{ Ref. } \\
\hline & & & & & & $\begin{array}{l}\text { No. of patients } \\
\text { with response }\end{array}$ & $\begin{array}{l}\text { No. of patients } \\
\text { with tumor } \\
\text { Prgrsn }\end{array}$ & $T T P$ & Survival & $\begin{array}{l}\text { Viral } \\
\text { genes }\end{array}$ & Shed virus & $A b$ & $\begin{array}{l}\text { Grade } 3 \text { or } 4 \\
\text { adverse events }\end{array}$ & \\
\hline & $\begin{array}{l}\text { CRC liver } \\
\text { mets }\end{array}$ & $\begin{array}{l}\text { NV1020 } \\
\text { (deleted } 1 \\
\text { copy g34.5, } \\
\text { UL24, UL56) }\end{array}$ & & & & $\begin{array}{l}\downarrow \text { CEA in } \\
9 / 9 \text { patients }\end{array}$ & & & $\begin{array}{l}\text { Median } \\
24 \text { months }\end{array}$ & & $\begin{array}{l}1 / 9 \text { saliva } \\
\text { and } 2 / 9 \\
\text { serum } \mathrm{PCR}^{+}\end{array}$ & & $\begin{array}{l}3 \text { serious adverse } \\
\text { events in } 3 \\
\text { patients; grade } \\
\text { not stated }\end{array}$ & $\begin{array}{l}\text { Fong et al. } \\
(2002)\end{array}$ \\
\hline \multicolumn{15}{|l|}{$N D V$} \\
\hline I/USA & $\begin{array}{l}\text { Advanced } \\
\text { solid }\end{array}$ & PV 701 & $\begin{array}{l}\text { Dose escalation to first } \\
\text { dose } \mathrm{MTD}=1.2 \times 10^{10} \\
\mathrm{PFU} / \mathrm{m}^{2} \text {; subsequent } \\
\text { dose MTD }=1.2 \times 10^{11} \\
\mathrm{PFU} / \mathrm{m}^{2}\end{array}$ & i.v. & 79 & $9 / 62(15 \%)$ & $53 / 62(85 \%)$ & $\mathrm{N} / \mathrm{S}$ & $\mathrm{N} / \mathrm{S}$ & $1 / 1$ by EM & $\mathrm{N} / \mathrm{S}$ & $\begin{array}{l}1 / 32 \text { at } \\
\text { start; } 27 / 29 \\
\text { at end }\end{array}$ & $\begin{array}{l}21 \text { grade } 3 \text { events; } \\
0 \text { grade } 4 \text { events }\end{array}$ & $\begin{array}{l}\text { Pecora et al. } \\
(2002)\end{array}$ \\
\hline I/Canada & $\begin{array}{l}\text { Advanced } \\
\text { solid }\end{array}$ & PV 701 & $\begin{array}{l}\text { Dose escalation to first } \\
\text { dose MTD }=12 \text { billion } \\
\text { PFU } / \mathrm{m}^{2} \text {; doses } 2-6 \\
\text { escalated to } 24-120 \\
\text { billion PFU } / \mathrm{m}^{2}\end{array}$ & i.v. & 11 & $4 / 8(50 \%)$ & $1 / 8(13 \%)$ & $\mathrm{N} / \mathrm{S}$ & $\mathrm{N} / \mathrm{S}$ & $\mathrm{N} / \mathrm{S}$ & $\mathrm{N} / \mathrm{S}$ & $\mathrm{N} / \mathrm{S}$ & $\mathrm{N} / \mathrm{S}$ & $\begin{array}{l}\text { Hotte et al. } \\
(2003)\end{array}$ \\
\hline I-II/Israel & GBM & OV 001 & $\begin{array}{l}10^{8}-10^{10} \mathrm{IU} / \mathrm{q} \cdot \mathrm{d} . \times 5 \\
\text { days per week } \times 1-2 \\
\text { weeks }\end{array}$ & i.v. & 7 & $1 / 7(14 \%)$ & $5 / 7(71 \%)$ & $\mathrm{N} / \mathrm{S}$ & $\mathrm{N} / \mathrm{S}$ & $\begin{array}{l}\text { Virus re- } \\
\text { covered in } \\
1 / 7 \text { biopsies }\end{array}$ & $\mathrm{N} / \mathrm{S}$ & $7 / 7$ & None & $\begin{array}{l}\text { Freeman et al. } \\
\text { (2004) }\end{array}$ \\
\hline $\begin{array}{l}\text { Reovirus } \\
\text { I/Canada }\end{array}$ & $\begin{array}{l}\text { Various } \\
\text { palpable } \\
\text { lesions }\end{array}$ & Reolysin & $\begin{array}{l}10^{7}-10^{10} \mathrm{PFU} / \text { single } \\
\text { or } 3 \text { injections q2d }\end{array}$ & i.t. & 18 & $2 / 18(11 \%)$ & $8 / 18(44 \%)$ & $\mathrm{N} / \mathrm{S}$ & $\mathrm{N} / \mathrm{S}$ & $\mathrm{N} / \mathrm{S}$ & $\begin{array}{l}\text { Serum } \\
\text { PCR }^{+} \text {in all } \\
\text { multi-injects }\end{array}$ & $18 / 18$ & None & $\begin{array}{l}\text { Morris et al. } \\
\text { (2002) }\end{array}$ \\
\hline \multicolumn{15}{|c|}{ Vaccinia virus } \\
\hline I/USA & Bladder & Dryvax & $\begin{array}{l}10^{6}-10^{8} \mathrm{PFU} / \\
\text { dose } \times 3 \text { doses }\end{array}$ & $\begin{array}{l}\text { Intrave- } \\
\text { sical }\end{array}$ & 4 & $\mathrm{~N} / \mathrm{S}$ & $\mathrm{N} / \mathrm{S}$ & $\mathrm{N} / \mathrm{S}$ & $\begin{array}{l}3 / 4 \text { at } 4 \\
\text { years }\end{array}$ & $\begin{array}{l}4 / 4 \text { with } \\
\text { vacuoles on } \\
\text { IHC }\end{array}$ & $\mathrm{N} / \mathrm{S}$ & $\mathrm{N} / \mathrm{S}$ & None & $\begin{array}{l}\text { Gomella et al. } \\
\text { (2001) }\end{array}$ \\
\hline $\mathrm{I} / \mathrm{USA}$ & Melanoma & $\begin{array}{l}\text { JX-594 } \\
\text { (GM-CSF) }\end{array}$ & $\begin{array}{l}10^{4}-8 \times 10^{7} \mathrm{PFU} / \\
\text { tiw } \times 6 \text { doses }\end{array}$ & i.t. & 7 & $4 / 6(67 \%)$ & $2 / 6(33 \%)$ & $\mathrm{N} / \mathrm{S}$ & $\mathrm{N} / \mathrm{S}$ & $\begin{array}{l}2 / 3 \mathrm{GM}^{+} \\
\mathrm{CSF}^{+} \text {by } \mathrm{i} \\
\mathrm{RT}-\mathrm{PCR} \\
\text { of bx }\end{array}$ & $\begin{array}{l}\text { No GM-CSF } \\
\text { in sera }\end{array}$ & $\mathrm{N} / \mathrm{S}$ & None & $\begin{array}{l}\text { Mastrangelo } \\
\text { et al. (1999) }\end{array}$ \\
\hline I/Australia & $\begin{array}{l}\text { Mesothel- } \\
\text { ioma }\end{array}$ & $\begin{array}{l}\text { NYCBOH } \\
\text { (IL-2) }\end{array}$ & $\begin{array}{l}10^{7} \mathrm{PFU} / \mathrm{qw} \times 1-3 \\
\text { doses }\end{array}$ & i.t. & 6 & $0 / 6$ & $6 / 6(100 \%)$ & $\mathrm{N} / \mathrm{S}$ & $\mathrm{N} / \mathrm{S}$ & $\begin{array}{l}4 / 6 \text { by RT-I } \\
\text { PCR of bx }\end{array}$ & None & $\mathrm{N} / \mathrm{S}$ & None & $\begin{array}{l}\text { Mukherjee } \\
\text { et al. (2000) }\end{array}$ \\
\hline
\end{tabular}

Prgrsn: progression; TTP: time to progression; Ab: neutralizing antibody; Ref.: reference; HNSCC: head and neck squamous cell carcinoma; PFU: plaque-forming units; i.t.: intratumoral; N/S: not stated; ISH: in situ hybridization; q.d.: once daily; qw: once a week; q2d: every two days; tiw: three times in a week; b.i.d.: twice a day; vp: viral particles; PCR: polymerase chain reaction; i.p.: intraperitoneal; i.v.: intravenous; s.c.: subcutaneous; 5-FU: 5-fluorouracil; IHC: immunohistochemistry; HCC: hepatocellular carcinoma; CRC: colorectal carcinoma; EM: electron microscopy; h.a.i.: hepatic artery infusion; mets: metastases; bx: biopsy; GBM: glioblastoma multiforme; sx: symptoms; HSV-1: herpes simplex virus type 1; NDV: Newcastle disease virus. Adverse events are as classified by the National Cancer Institute scale 
maximum tolerable dose, such as adenovirus. CV706 is a replication-competent, E3-deleted cytolytic Ad5 adenovirus in which a minimal promoter enhancer of the human PSA gene has been placed between E1A and its promoter, causing PSA-regulated expression of E1A. In a phase I trial, 20 patients with locally recurrent prostate cancer after radiation therapy were treated with intraprostatic injections of up to $10^{13}$ viral particles (DeWeese et al., 2001). All five patients who achieved a $50 \%$ or more reduction in PSA were treated with the two highest doses of CV706.

\section{Transgenes used in cancer gene therapy}

Unlike nononcolytic vectors, oncolytic viruses do not require inserted transgenes with a tumoricidal effect in order to be effective therapeutic agents. However, oncolytic viruses can still gain an extra anticancer effect by the insertion of certain transgenes. Transgene types that have been inserted into oncolytic viruses in clinical trials include immune response-modifying genes (cytokines) and prodrug-activating enzymes.

\section{Immune response-modifying genes}

Cytokines as transgenes in oncolytic viruses are best suited for viruses that generate a strong immune response that can potentially extend into an antitumor immune response, such as vaccinia or HSV. The cytokines that have been tested so far are GM-CSF and IL-2, which both contribute to the activation of $\mathrm{T}$ cells, a key mediator of the antitumoral immune response.

A vaccinia mutant encoding GM-CSF was given to patients with cutaneous melanoma (Mastrangelo et al., 1999). No serious toxicity occurred, and the most frequent side effects were local inflammation and flu-like symptoms. Viral mRNA expression was detected in two-thirds of biopsy samples, but no patients showed detectable GM-CSF in serum. In addition, significant eosinophil, lymphocyte, and macrophage infiltration was found in all tumors. Overall response rate was $67 \%$.

Another vaccinia mutant encoding IL-2 was tested in six mesothelioma patients in a trial in Australia (Mukherjee et al., 2000). No toxicity occurred, and viral mRNA was detected in two-thirds of tumor biopsy samples 21 days after last treatment. In addition, T-lymphocyte infiltration was noted in all tumors. However, all patients had progression of disease.

Oncolytic HSV vector OncoVEX ${ }^{\mathrm{GM}-\mathrm{CSF}}$, which contains deletions in $\gamma 34.5$ and ICP 47 (which precludes MHC class I presentation) and also contains a GM-CSF transgene insertion, underwent a phase I clinical trial in patients with cutaneous and subcutaneous metastases from a variety of primary tumors. Eight patients were treated at $10^{6}$ and $10^{7} \mathrm{PFU}$, with evidence of viral replication, tumor necrosis, and inflammation consistent with GM-CSF expression (Hu et al., 2003).

\section{Prodrug-activating enzymes}

Prodrugs are chemicals that are inert over a wide range of doses but converted into toxic molecules by specific prodrug-activating enzymes. Genes encoding for prodrug-activating enzymes are appealing transgenes in cancer gene therapy because of their prominent bystander effects, generated by the ability of the active metabolite of the prodrug to mediate toxicity of neighboring nontransduced cells. The two examples that have made it to clinical trials with oncolytic viruses are HSV-TK, which phosphorylates the antiherpetic agent GCV, and $E$. coli cytosine deaminase, which converts antifungal agent 5-flurocytosine into chemotherapy agent 5-FU (Aghi et al., 2000). Engineered adenovirus Ad5-CD/TK has an E1B-55K deletion and an insertion of a $\mathrm{CD} / \mathrm{HSV}-\mathrm{TK}$ fusion gene. In a phase I clinical trial, 16 patients with newly diagnosed intermediate- to high-risk prostate cancer received intraprostatic injections escalating up to $10^{12}$ viral particles (Freytag et al., 2002). After 2 days, 5-fluorocytosine and valganciclovir were administered for varying amounts of time. There were no significant adverse effects. Seven of $16(44 \%)$ patients demonstrated a $25 \%$ or higher decrease in serum PSA and three of 16 (19\%) demonstrated a $50 \%$ or higher decrease in serum PSA (Freytag et al., 2002). A follow-up phase I trial by the same group combining this virus with radiation therapy was described earlier in the section highlighting trials combining viruses with radiation therapy.

\section{Lessons learned and future directions}

Since the first clinical trial using oncolytic viruses was initiated with ONYX-015 in 1996, five different species of viruses have entered phase I or II clinical trials on over 300 cancer patients. Encouraging data have led to a phase III clinical trial in which ONYX-015 plus chemotherapy will be compared to chemotherapy alone in approximately 300 patients with recurrent head and neck cancer. Results from such a study will provide the first sense of whether oncolytic viruses warrant consideration as part of certain existing anticancer therapeutic regimens.

Considerable safety data have accumulated from the numerous completed phase I or II clinical trials. Of over 300 patients treated, only one treatment-related death has been reported to date, from intravenous NDV, and this death may have resulted from rapid tumor lysis, underscoring the importance of selecting patients with adequate pretreatment functional reserve. While certain levels of toxicity may be acceptable in experimental cancer therapies, the risk of rapid treatment-related mortalities should be minimized by adequate patient selection criteria as well as by having a 'fail-safe' mechanism built into the vector to allow a systemic agent to be administered to abort viral replication.

There are issues specific to certain types of tumors. For example, high-grade gliomas are among the least easily accessed tumor types to undergo oncolytic virus 

with neurosurgical procedures compared with diagnostic procedures in other cancer types. Gliomas have undergone oncolytic virus treatment by stereotactic inoculation during needle-guided biopsies, as well as using multiple inoculations during a craniotomy. A craniotomy allows inoculation along multiple needle tracts, causing more widespread viral distribution, but leaves a postsurgical cavity in which virus can accumulate if intraparenchymal pressure drives the inoculum out of its needle tracts. Stereotactic inoculation limits viral distribution and total dose, but is a safer lessexpensive procedure, an important factor if a follow-up craniotomy is required to obtain tissue to assess viral replication. The relative merits of both approaches will become better understood as more clinical data are reported. Treating gliomas with oncolytic viruses will likely be far more challenging than other tumors because of the highly invasive nature of glioblastoma. One study estimated that replicating viral infection travels at a speed of about three cell radii divided by the infected cell lifetime, which is roughly $30 \mu \mathrm{m} / 24 \mathrm{~h}=0.02 \mathrm{~cm} /$ week for adenovirus, and $30 \mu \mathrm{m} / 12 \mathrm{~h}=0.04 \mathrm{~cm} /$ week for $\mathrm{HSV}$ (Wu et al., 2004). This is 5-10 times slower than the tumor wave front invasive velocity (Wu et al., 2004). One method of increasing the distribution of oncolytic viruses in the brain may be convection-enhanced delivery in which a catheter placed during surgery might provide convection-enhanced delivery of oncolytic viruses over a few days after surgery, improving viral distribution in the brain relative to injections during surgery that rely on diffusion (MacKay et al., 2005).

There are also issues relating to cost. While viruses such as NDV have been dose-escalated up to a maximum tolerable dose, other viruses such as HSV have had a very good safety profile and therefore have yet to define a maximum tolerable dose but have generated sufficient production costs that some trials have had to dose escalate up to a 'maximum affordable dose.' For these types of viruses, defining a maximum tolerable dose will require greater financial support of clinical trials and more cost-efficient technologies for viral production. An alternative strategy is the exploration of agents that may enhance in vivo viral replication.

For that matter, the role of dose in oncolytic virus therapy remains unclear. While viruses such as NDV have caused greater therapeutic benefit at higher doses, the benefit of higher doses with viruses such as HSV remains unclear. The inability of some viruses to elicit a therapeutic benefit at higher doses may be immunemediated, a possibility that should be assessed using data from clinical trials. Ultimately, there may be a unique optimal treatment protocol for each viral species. For example, NDV toxicity appears to be reduced by prolonging the infusion time from 1 to $3 \mathrm{~h}$ (Hotte et al., 2003). And other viruses such as ONYX-015 appear to be more effective when delivered through hyperfractionated intratumoral inoculations such as twice a day for 5 days per week for 2 weeks rather than standard treatment protocols (Nemunaitis et al., 2001).

In fact, the role of the immune responses is unclear, with some preclinical data suggesting that immunity to a virus, whether innate or acquired, might restrict viral replication. Alternatively, an immune response against infected tumor cells could also enhance tumor destruction, as specific host immunity develops against tumor antigens. Route of administration may play a role. It is possible that the immune system antagonizes the efficacy of oncolytic viruses administered intravascularly by limiting viral delivery to the tumor. However, once the virus reaches tumor cells, as it does immediately with intratumoral inoculation, the immune response may augment tumor reduction by redirecting the cytotoxic T-cell response from viral antigens to tumor antigens (Todo et al., 1999). When administering an immunogenic virus in a situation where the immune response is likely to impede viral replication, it may be essential to use a virus with a short replication cycle (Table 1).

Given the costs of clinical trials, organizers must maximize data obtained from each trial. For example, incorporating the $\mathrm{Na} / \mathrm{I}$ symporter into a virus can allow the virus to be traced by positron emission tomography (PET) (Groot-Wassink et al., 2002). Mathematical models that calculate the kinetics of viral replication can be used to determine the number of viral genome copies in the circulation as a function of time based on lab values from available blood samples obtained during clinical trials (Wein et al., 2003). Engineering viruses to secrete soluble proteins whose levels can be assessed in serum or tumor samples to determine degree of viral replication can make monitoring more feasible and costefficient (Peng et al., 2002).

Finally, there is a need for standardized measurements between viruses to assist in comparing them. Since nonreplicating viruses can themselves induce an immune response or toxicity, dosing considerations may also include the number of viral particles in addition to plaque-forming units, and relationships between viral particles and plaque-forming units should be made clear when publishing results. In addition, most clinical trials have reported effects on surrogate end points such as PSA levels or transient injection site responses. These end points are not validated as predictive of survival or clinical benefit. There is a need for validated end points such as survival and quality of life in order to render data between different trials more readily comparable.

\section{Conclusions}

Although the concept of using viruses as oncolytic agents dates back nearly a century, formal clinical experience could not be achieved until advances in molecular biology, genetics, and virology enabled engineering DNA viruses to achieve tumor selectivity or identification of RNA viruses with intrinsic tumor selectivity. The 9 years worth of clinical experience that have been achieved with oncolytic viruses have produced enough therapeutic efficacy to trigger optimism 
for future trials. Although the initial concerns of clinical investigators were for safety, this has proven not to be a common concern in these trials. Now, efforts must be aimed at improving efficacy. The results of these clinical trials must be thoroughly analysed and, if necessary,

\section{References}

Aghi M, Hochberg F and Breakefield XO. (2000). J. Gene Med., 2, 148-164.

Assessment of adenoviral vector safety and toxicity: report of the National Institutes of Health Recombinant DNA Advisory Committee (2002) 13, 3-13.

Batliwalla FM, Bateman BA, Serrano D, Murray D, Macphail S, Maino VC, Ansel JC, Gregersen PK and Armstrong CA. (1998). Mol. Med., 4, 783-794.

Bischoff JR, Kirn DH, Williams A, Heise C, Horn S, Muna M, Ng L, Nye JA, Sampson-Johannes A, Fattaey A and McCormick F. (1996). Science, 274, 373-376.

Boviatsis EJ, Park JS, Sena-Esteves M, Kramm CM, Chase M, Efird JT, Wei MX, Breakefield XO and Chiocca EA. (1994a). Cancer Res., 54, 5745-5751.

Boviatsis EJ, Scharf JM, Chase M, Harrington K, Kowall NW, Breakefield XO and Chiocca EA. (1994b). Gene Therapy, 1, 323-331.

Brown SM, MacLean AR, McKie EA and Harland J. (1997). J. Virol., 71, 9442-9449.

Chiocca EA, Abbed KM, Tatter S, Louis DN, Hochberg FH, Barker F, Kracher J, Grossman SA, Fisher JD, Carson K, Rosenblum M, Mikkelsen T, Olson J, Markert J, Rosenfeld S, Nabors LB, Brem S, Phuphanich S, Freeman S, Kaplan R and Zwiebel J. (2004). Mol. Ther., 10, 958-966.

Coffey MC, Strong JE, Forsyth PA and Lee PW. (1998). Science, 282, 1332-1334.

DeWeese TL, van der Poel H, Li S, Mikhak B, Drew R, Goemann M, Hamper U, DeJong R, Detorie N, Rodriguez R, Haulk T, DeMarzo AM, Piantadosi S, Yu DC, Chen Y, Henderson DR, Carducci MA, Nelson WG and Simons JW. (2001). Cancer Res., 61, 7464-7472.

Edelstein M. (2005). Journal of Gene Medicine. World wide web: http://www.wiley.co.uk/genmed/clinical: Wiley Publishers.

Enserink M. (2002). Science, 298, 2313.

Fong YKN, Jarnagin W, Stanziale S, Guilfoyle B, Gusani N, Joe J, Blumgart L, Lakeman F, Gammon K, Perterkin J, Horsburgh B and Tufaro F. (2002). 38th Annual Meeting of the American Society of Clinical Oncology (ASCO) Orlando, FL.

Freeman AI, Gomori JM, Linetsky E, Zakay-Rones Z, Panet A, Libson E, Irving CS, Galun E and Siegal T. (2004). 40th Annual Meeting of the American Society of Clinical Oncology ( $A S C O)$ New Orleans, LA.

Freytag SO, Khil M, Stricker H, Peabody J, Menon M, DePeralta-Venturina M, Nafziger D, Pegg J, Paielli D, Brown S, Barton K, Lu M, Aguilar-Cordova E and Kim JH. (2002). Cancer Res., 62, 4968-4976.

Freytag SO, Stricker H, Pegg J, Paielli D, Pradhan DG, Peabody J, DePeralta-Venturina M, Xia X, Brown S, Lu M and Kim JH. (2003). Cancer Res., 63, 7497-7506.

Galanis E, Okuno SH, Nascimento AG, Lewis BD, Lee RA, Oliveira AM, Sloan JA, Atherton P, Edmonson JH, Erlichman C, Randlev B, Wang Q, Freeman S and Rubin J. (2005). Gene Therapy, 12, 437-445.

Ganly I, Kirn D, Eckhardt G, Rodriguez GI, Soutar DS, Otto R, Robertson AG, Park O, Gulley ML, Heise C, Von Hoff DD and Kaye SB. (2000). Clin. Cancer Res., 6, 798-806. brought back to the laboratory to make appropriate adjustments so that future oncolytic virus clinical trials make the necessary steps forward toward the goal of making oncolytic viruses a standard agent in the battle against cancer.

Gomella LG, Mastrangelo MJ, McCue PA, Maguire HJ, Mulholland SG and Lattime EC. (2001). J. Urol., 166, 1291-1295.

Goodrum FD and Ornelles DA. (1998). J. Virol., 72, 9479-9490.

Groot-Wassink T, Aboagye EO, Glaser M, Lemoine NR and Vassaux G. (2002). Hum. Gene Ther., 13, 1723-1735.

Habib N, Salama H, Abd El Latif Abu Median A, Isac Anis I, Abd Al Aziz RA, Sarraf C, Mitry R, Havlik R, Seth P, Hartwigsen J, Bhushan R, Nicholls J and Jensen S. (2002). Cancer Gene Ther., 9, 254-259.

Habib NA, Sarraf CE, Mitry RR, Havlik R, Nicholls J, Kelly M, Vernon CC, Gueret-Wardle D, El-Masry R, Salama H, Ahmed R, Michail N, Edward E and Jensen SL. (2001). Hum. Gene Ther., 12, 219-226.

Hamid O, Varterasian ML, Wadler S, Hecht JR, Benson 3rd A, Galanis E, Uprichard M, Omer C, Bycott P, Hackman RC and Shields AF. (2003). J. Clin. Oncol., 21, 1498-1504.

Harrow S, Papanastassiou V, Harland J, Mabbs R, Petty R, Fraser M, Hadley D, Patterson J, Brown SM and Rampling R. (2004). Gene Therapy, 11, 1648-1658.

Hecht JR, Bedford R, Abbruzzese JL, Lahoti S, Reid TR, Soetikno RM, Kirn DH and Freeman SM. (2003). Clin. Cancer Res., 9, 555-561.

Heise C, Sampson-Johannes A, Williams A, McCormick F, Von Hoff DD and Kirn DH. (1997). Nat. Med., 3, 639-645.

Heise CC, Williams AM, Xue S, Propst M and Kirn DH. (1999). Cancer Res., 59, 2623-2628.

Hermann LL and Coombs KM. (2004). J. Virol., 78, 6171-6179.

Hotte SJ, Major PP, Hirte HW, Polawski S, Bamat MK, Rheaume N and Lorence RM. (2003). 39th Annual Meeting of the American Society of Clinical Oncology (ASCO) Chicago, IL.

$\mathrm{Hu}$ JCMC, Shorrock J, Steiner C, Love R and Coffin C. (2003). 39th Annual Meeting of the American Society of Clinical Oncology ( ASCO) Chicago, IL, abstract 742.

Khuri FR, Nemunaitis J, Ganly I, Arseneau J, Tannock IF, Romel L, Gore M, Ironside J, MacDougall RH, Heise C, Randlev B, Gillenwater AM, Bruso P, Kaye SB, Hong WK and Kirn DH. (2000). Nat. Med., 6, 879-885.

Kramm CM, Chase M, Herrlinger U, Jacobs A, Pechan PA, Rainov NG, Sena-Esteves M, Aghi M, Barnett FH, Chiocca EA and Breakefield XO. (1997). Hum. Gene Ther., 8, 2057-2068.

Lee SS, Eisenlohr LC, McCue PA, Mastrangelo MJ and Lattime EC. (1994). Cancer Res., 54, 3325-3328.

Lorence RM, Rood PA and Kelley KW. (1988). J. Natl. Cancer Inst., 80, 1305-1312.

MacKay JA, Deen DF and Szoka Jr FC. (2005). Brain Res., 1035, 139-153.

MacKie RM, Stewart B and Brown SM. (2001). Lancet, 357, 525-526.

Makower D, Rozenblit A, Kaufman H, Edelman M, Lane ME, Zwiebel J, Haynes H and Wadler S. (2003). Clin. Cancer Res., 9, 693-702.

Markert JM, Medlock MD, Rabkin SD, Gillespie GY, Todo T, Hunter WD, Palmer CA, Feigenbaum F, Tornatore C, 
Tufaro F and Martuza RL. (2000). Gene Therapy, 7, 867-874.

Martuza RL, Malick A, Markert JM, Ruffner KL and Coen DM. (1991). Science, 252, 854-856.

Mastrangelo MJ, Maguire Jr HC, Eisenlohr LC, Laughlin CE, Monken CE, McCue PA, Kovatich AJ and Lattime EC. (1999). Cancer Gene Ther., 6, 409-422.

Mohr I and Gluzman Y. (1996). EMBO J., 15, 4759-4766.

Morley S, MacDonald G, Kirn D, Kaye S, Brown R and Soutar D. (2004). Clin. Cancer Res., 10, 4357-4362.

Morris DG, Forsyth PA, Paterson AH, Fonseca K, Difrancesco LM, Thompson BG and Coffey MC. (2002). 38th Annual Meeting of the American Society for Clinical Oncology ( ASCO) Orlando, FL.

Mukherjee S, Haenel T, Himbeck R, Scott B, Ramshaw I, Lake RA, Harnett G, Phillips P, Morey S, Smith D, Davidson JA, Musk AW and Robinson B. (2000). Cancer Gene Ther., 7, 663-670.

Mulvihill S, Warren R, Venook A, Adler A, Randlev B, Heise $\mathrm{C}$ and Kirn D. (2001). Gene Therapy, 8, 308-315.

Nemunaitis J, Cunningham C, Buchanan A, Blackburn A, Edelman G, Maples P, Netto G, Tong A, Randlev B, Olson S and Kirn D. (2001). Gene Therapy, 8, 746-759.

Nemunaitis J, Cunningham C, Tong AW, Post L, Netto G, Paulson AS, Rich D, Blackburn A, Sands B, Gibson B, Randlev B and Freeman S. (2003). Cancer Gene Ther., 10, 341-352.

Nemunaitis J, Ganly I, Khuri F, Arseneau J, Kuhn J, McCarty T, Landers S, Maples P, Romel L, Randlev B, Reid T, Kaye S and Kirn D. (2000). Cancer Res., 60, 6359-6366.

Nemunaitis J, Khuri F, Ganly I, Arseneau J, Posner M, Vokes E, Kuhn J, McCarty T, Landers S, Blackburn A, Romel L, Randlev B, Kaye S and Kirn D. (2001). J. Clin. Oncol., 19, 289-298.

O'Shea CC, Johnson L, Bagus B, Choi S, Nicholas C, Shen A, Boyle L, Pandey K, Soria C, Kunich J, Shen Y, Habets G, Ginzinger D and McCormick F. (2004). Cancer Cell, 6, 611-623.

Papanastassiou V, Rampling R, Fraser M, Petty R, Hadley D, Nicoll J, Harland J, Mabbs R and Brown M. (2002). Gene Therapy, 9, 398-406.

Pecora AL, Rizvi N, Cohen GI, Meropol NJ, Sterman D, Marshall JL, Goldberg S, Gross P, O’Neil JD, Groene WS,
Roberts MS, Rabin H, Bamat MK and Lorence RM. (2002). J. Clin. Oncol., 20, 2251-2266.

Peng KW, Facteau S, Wegman T, O'Kane D and Russell SJ. (2002). Nat. Med., 8, 527-531.

Rampling R, Cruickshank G, Papanastassiou V, Nicoll J, Hadley D, Brennan D, Petty R, MacLean A, Harland J, McKie E, Mabbs R and Brown M. (2000). Gene Therapy, 7 , 859-866.

Rauen KA, Sudilovsky D, Le JL, Chew KL, Hann B, Weinberg V, Schmitt LD and McCormick F. (2002). Cancer Res., 62, 3812-3818.

Reid T, Galanis E, Abbruzzese J, Sze D, Andrews J, Romel L, Hatfield M, Rubin J and Kirn D. (2001). Gene Therapy, 8, 1618-1626.

Reid T, Galanis E, Abbruzzese J, Sze D, Wein LM, Andrews J, Randlev B, Heise C, Uprichard M, Hatfield M, Rome L, Rubin J and Kirn D. (2002). Cancer Res., 62, 6070-6079.

Rogulski KR, Freytag SO, Zhang K, Gilbert JD, Paielli DL, Kim JH, Heise CC and Kirn DH. (2000). Cancer Res., 60, 1193-1196.

Rudin CM, Cohen EE, Papadimitrakopoulou VA, Silverman Jr S, Recant W, El-Naggar AK, Stenson K, Lippman SM, Hong WK and Vokes EE. (2003). J. Clin. Oncol., 21, 4546-4552.

Southam CM. (1960). Trans. NY Acad. Sci., 22, 657-673.

Todo T, Rabkin SD, Sundaresan P, Wu A, Meehan KR, Herscowitz HB and Martuza RL. (1999). Hum. Gene Ther., 10, 2741-2755.

Vasey PA, Shulman LN, Campos S, Davis J, Gore M, Johnston S, Kirn DH, O'Neill V, Siddiqui N, Seiden MV and Kaye SB. (2002). J. Clin. Oncol., 20, 1562-1569.

Vogelstein B and Kinzler KW. (2004). Nat. Med., 10, 789-799. Wang Q, Guo J and Jia W. (1997). Gene Therapy, 4, $1300-1304$.

Wein LM, Wu JT and Kirn DH. (2003). Cancer Res., 63, 1317-1324.

Wu JT, Kirn DH and Wein LM. (2004). Bull. Math. Biol., 66, 605-625.

Xu RH, Yuan ZY, Guan ZZ, Cao Y, Wang HQ, Hu XH, Feng JF, Zhang Y, Li F, Chen ZT, Wang JJ, Huang JJ, Zhou QH and Song ST. (2003). Ai. Zheng, 22, 1307-1310.

Yuan ZY, Zhang L, Li S, Qian XZ and Guan ZZ. (2003). Ai. Zheng, 22, 310-313. 